\title{
The Diverse Contributions of Fucose Linkages in Cancer
}

\author{
Tyler S. Keeley ${ }^{1,2,3}$, Shengyu Yang ${ }^{1, *}$ and Eric Lau ${ }^{3, *}$ \\ 1 Department of Cellular and Molecular Physiology, Penn State College of Medicine, Hershey, PA 17033, USA \\ 2 University of South Florida Cancer Biology Graduate Program, Tampa, FL 33602, USA \\ 3 Department of Tumor Biology, H. Lee Moffitt Cancer Center, Tampa, FL 33602, USA \\ * Correspondence: sxy99@psu.edu (S.Y.); Eric.Lau@Moffitt.org (E.L.)
}

Received: 14 July 2019; Accepted: 20 August 2019; Published: 24 August 2019

\begin{abstract}
Fucosylation is a post-translational modification of glycans, proteins, and lipids that is responsible for many biological processes. Fucose conjugation via $\alpha(1,2), \alpha(1,3), \alpha(1,4), \alpha(1,6)$, and $\mathrm{O}^{\prime}-$ linkages to glycans, and variations in fucosylation linkages, has important implications for cancer biology. This review focuses on the roles that fucosylation plays in cancer, specifically through modulation of cell surface proteins and signaling pathways. How L-fucose and serum fucosylation patterns might be used for future clinical diagnostic, prognostic, and therapeutic approaches will be discussed.
\end{abstract}

Keywords: fucose; fucosylation; fucosyltransferase; cancer; signal transduction

\section{Introduction}

Fucose is a natural deoxyhexose sugar with similar structure to glucose, except for its lack of a hydroxyl group on carbon 6. Mammalian cells utilize fucose in the L-enantiomer form, whereas other deoxyhexoses are used in the D-enantiomer. L-Fucose is incorporated onto glycoproteins during the synthesis of $\mathrm{N}$ - and O-linked glycans in mammalian cells [1,2]. Fucosylated glycans elicit a range of functions from regulating inflammatory responses, signal transduction, cell growth, transcription, and adhesion [3]. For example, cell-cell interactions can be partially modulated by the presence of L-fucose specific-lectin-like adhesion molecules on the cell surface [4]. In addition, the fucosylation of cell membrane receptors and proteins, including EGFR, TGF $\beta$, Notch, E-cadherin, integrins, and selectin ligands, has been reported to influence their ligand binding, dimerization, and signaling capacities [5-8].

Cancer is characterized by the deregulation of otherwise normal cellular and molecular processes, which can restrict or suppress tumorigenesis, resulting in altered growth, survival, metabolism, and metastasis [9]. Post-transitional modifications, including fucosylation, represent an important regulatory layer that is subject to perturbation during carcinogenesis and tumor progression. Increasing numbers of studies have identified important and specific roles for fucosylated glycoconjugates in tumorigenesis and how they correlate with the established hallmarks of cancer [10]. Deregulation of fucosylation has been reported in several cancer types, and the resulting divergent functional consequences are likely attributed to the presence/absence of specific structural types of fucosylation branching that can differentially influence protein function [11,12]. Increased fucosylation has been attributed to metastatic properties such as, for example, enhancing adhesion of metastatic cancer cells to endothelia cells $[1,4,13]$. However, fucosylation has also been reported to suppress motility in cancers such as melanoma [14,15], oral/head and neck [16], and hepatocellular carcinoma (HCC) [17]. Here, we have examined and summarized the literature in order to highlight alterations 
in fucosylation across various cancer types and whether fucosylation branches are associated with divergent pathological phenotypes.

\section{Fucose Metabolism}

In mammalian cells, fucosylation starts with substrate (GDP-fucose) generation, which can occur via the de novo and/or salvage pathways (Figure 1). In the de novo pathway, GDP-mannose in the cytosol is converted to GDP-4-keto-deoxymannose by GDP-mannose 4,6-dehydratase (GMD). The keto intermediate is rapidly converted to GDP-4-keto-6-deoxygalactose by the NADP(H)-binding epimerase-reductase FX protein to GDP-fucose [1]. In the salvage pathway, L-fucose is transported into the cytosol from the extracellular space or from lysosomal compartments, by mechanisms that remain relatively undefined in mammalian cells [18]. Free L-fucose in the cytosol is phosphorylated by fucokinase (FUK). The resulting fucose-1-phosphate is converted to GDP-fucose by GDP-pyrophosphorylase [1]. GDP-fucose is then transported into the Golgi apparatus, where it is used as a substrate for protein fucosylation that is mediated by fucosyltransferases. Alternatively, GDP-fucose can also be conjugated onto proteins by Protein O-fucosyltransferases (POFUTs) in the endoplasmic reticulum [19-21]. A recent study by $\mathrm{Ng}$ et al. reported that human patients with pathogenic mutations in FUK present with severe developmental impairments including encephalopathy, hypotonia, and seizures [22]. These data suggest tissue type-dependent reliance on de novo synthesis vs. salvage pathway-derived GDP-fucose.

The main source of L-fucose for the salvage pathway comes from diet, predominantly from plant sources such as seaweed [23]. However, when dietary sources are insufficient, L-fucose can be catabolized from preexisting fucosylated glycoconjugates or supplemented by the de novo pathway. The glycoconjugates are endocytosed and catabolized in lysosomes, where fucosidases liberate L-fucose from the glycans, rendering them once again useable via the salvage pathway. This mechanism has been reported to generate sufficient GDP-fucose to sustain physiological functions of the cell when de novo pathway activity is insufficient or pathologically abrogated, provided that exogenous supraphysiological L-fucose concentrations are available to cells [1,24].

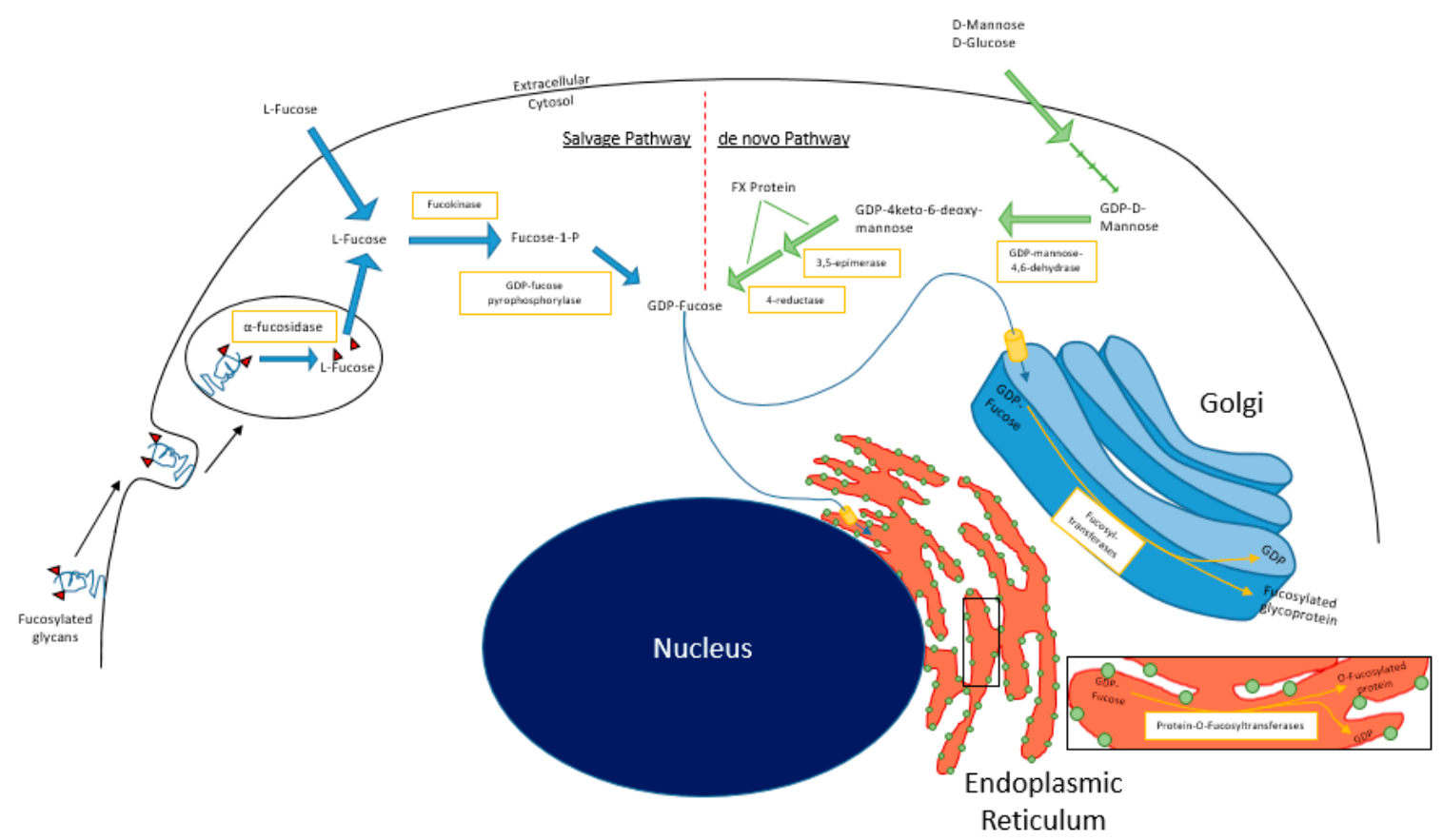

Figure 1. Fucose salvage and de novo pathways. 


\section{Fucosyltransferases: Architects of Fucosylation Branching}

Fucose can be conjugated onto oligosaccharides in the following specific orientations: $\alpha(1,2)$, $\alpha(1,3), \alpha(1,4)$, and $\alpha(1,6)$ orientations, where the first carbon of fucose is bound to the $(1,2),(1,3),(1,4)$, or $(1,6)$ carbon of galactose or $\mathrm{N}$-acetylglucosamine (GlcNAc) $[25,26]$. The $\alpha$-fucose conjugations can occur at core or terminal positions along glycans (Figure 2). Core fucosylation has been reported to play important roles in influencing the signaling capacity of membrane-bound proteins including EGFR. T cell receptors are heavily core fucosylated, which ensures proper activation and downstream signaling [27]. Notably, only FUT8 has been identified to mediate core fucosylation (via " $\mathrm{N}^{\prime}$-linkages"), wherein fucose is conjugated to a primary $\mathrm{N}$-acetylglucosamine branch (GlcNAc) on N-glycans [28]. Terminal fucosylation refers to fucose conjugated to GlcNAc monosaccharides (also known as $\alpha(1,3)$ or $\alpha(1,4)$ branching) or to galactose residues (also known as $\alpha(1,2)$ branching) (Figure 2) [2,28].

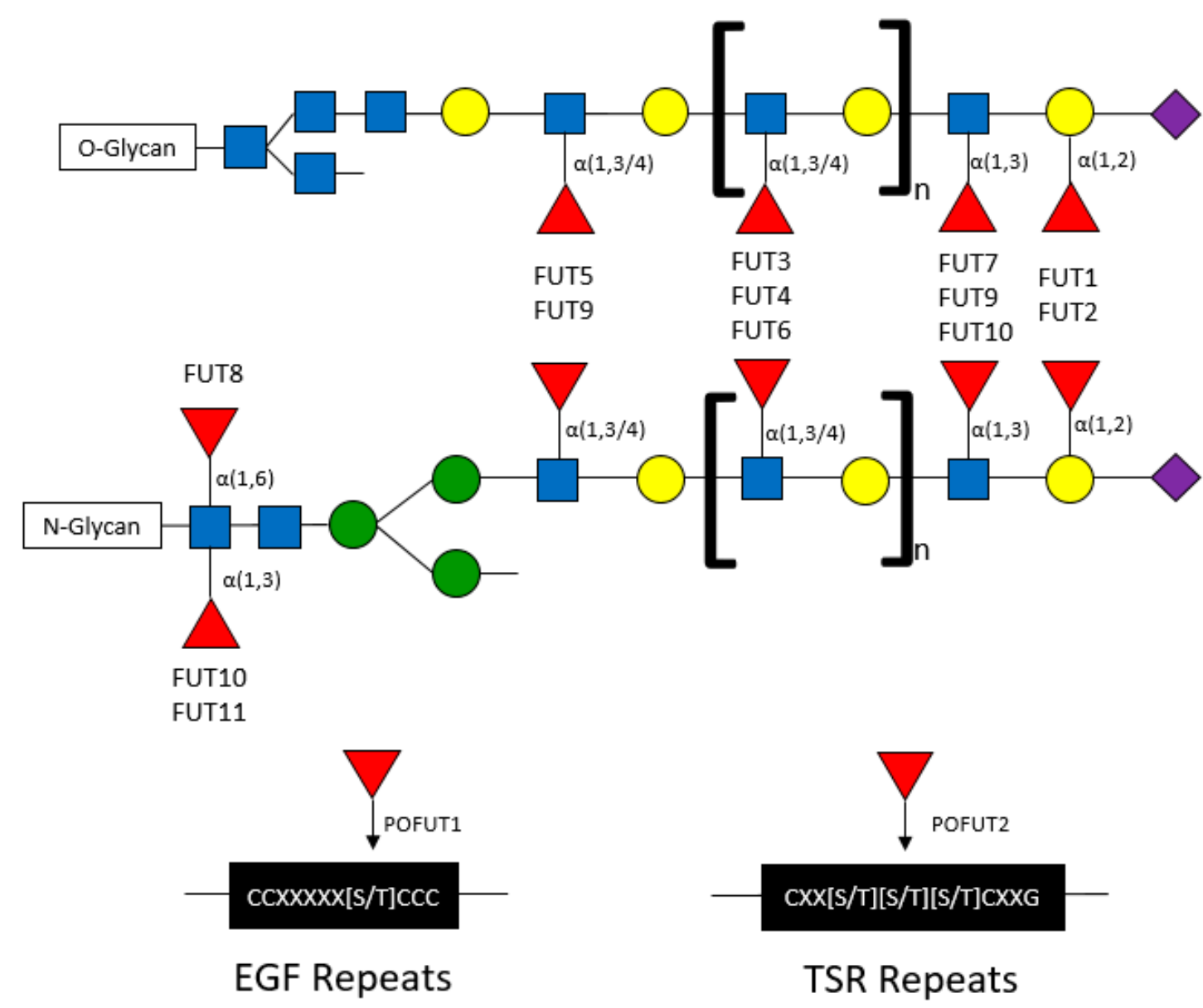

Figure 2. Fucosyltransferases and their associated conjugated fucose structures.

Terminal fucosylated structures are highly diverse, contributing to the generation of Lewis antigens on a multitude of proteins [29]. The topological landscape of fucosylated glycans and their functional consequences are dictated by fucosyltransferases (FUTs). Methods for detecting specific fucosylated structures include mass spectrometry, as well as binding/pulldown approaches using lectins with binding affinities for fucosylated structures (Table 1).

Fucosyltransferases are membrane-bound proteins residing in the endoplasmic reticulum and Golgi. To date, 11 FUTs and 2 protein O-fucosyltransferases (POFUTs) have been discovered. FUTs and POFUTs transfer fucose using GDP-fucose as a substrate to oligosaccharides, glycans, lipids, and proteins to form fucosylated glycoconjugates [21,28,30,31]. Additionally, fucose can be directly O-link conjugated onto serine or threonine residues of Epidermal Growth Factor (EGF)-like repeats 
by POFUT1 and Thrombospondin Type 1 (TSR) repeats by POFUT2 [19-21,28]. The vast array of FUT-mediated fucosylation (and fucosylated target proteins) has been extensively characterized in non-cancer, particularly immunological, contexts. However, many of the immune proteins known to be fucosylated might also play roles in cancer. For example, the expression of Lewis (Le) antigens, which are oligosaccharide-based blood antigens containing differing orientations of fucosylation (Figure 3), correlate with cancer stage, tumor cell differentiation, decreased survival, and metastasis [32].

Table 1. Lectins commonly used in for the detection of specific branches of fucosylation.

\begin{tabular}{cccc}
\hline Fucosylation & $\alpha \mathbf{( 1 , 2 )}$ & $\alpha \mathbf{( 1 , 3 / 4 )}$ & $\alpha(\mathbf{1 , 6 )}$ \\
\hline Ulex Europaeus Agglutinin 1 (UEA-1) & $X$ & & \\
\hline Aleuria Aurantia Lectin (AAL) & & $X$ & $X$ \\
\hline Lens Culinaris Agglutinin (LCA) & & & $X$ \\
\hline Lotus Tetragonolobus Lectin (LTL) & $X$ & & \\
\hline
\end{tabular}
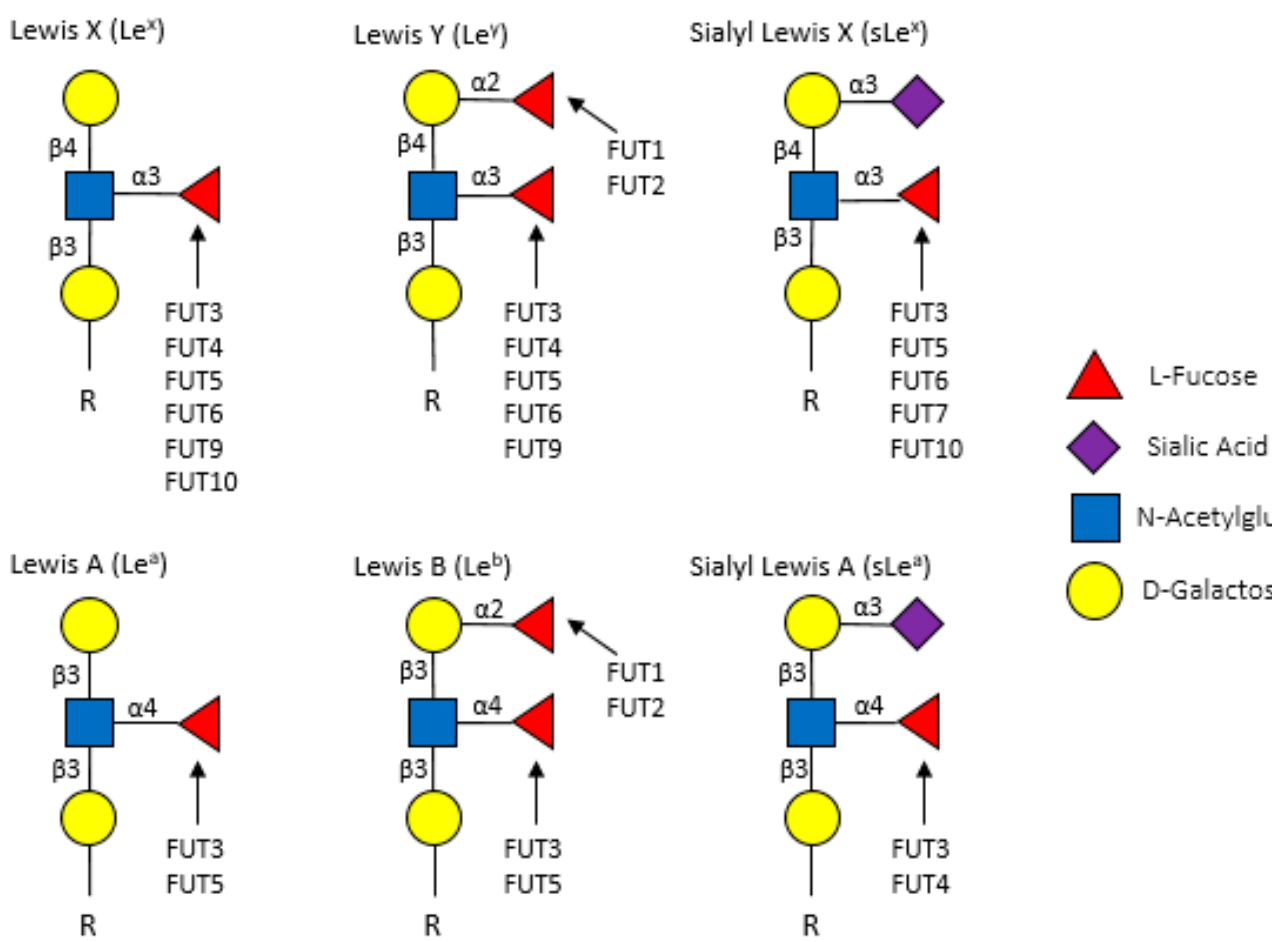

N-Acetylglucosamine

Figure 3. Lewis antigens commonly found in on the surface of cancer cells.

Fucosyltransferases can generally be grouped by the fucosylation linkages that they mediate (Table 2). FUT1 and FUT2 mediate $\alpha(1,2)$ fucosylation on terminal galactose residues on both Oand N-linked glycans. FUT3-7 and FUT9-11 are responsible for the addition of fucose to GlcNAc monosaccharides in $\alpha(1,3)$ and $\alpha(1,4)$ orientations on O- and N-glycans. FUT8 is the only transferase that has been shown to conjugate fucose to the initial GlcNAc residue on $\mathrm{N}$-glycans in $\alpha(1,6)$ branching (core fucosylation) structures. Although extensive studies have investigated the structural fucosylation linkages and functional effects mediated by these FUTs, the fucosylated targets are largely not well characterized. 
Table 2. Fucosylation linkages, associated FUTs, and targets

\begin{tabular}{|c|c|c|c|}
\hline Structural Linkage & FUTs & Targets \& Functions & Refs \\
\hline \multirow[t]{2}{*}{$\alpha(1,2)$} & FUT1 & $\begin{array}{l}\mathrm{H}, \mathrm{ABO} \text {, and Lewis }{ }^{\mathrm{y}}\left(\mathrm{Le}^{\mathrm{y}}\right) \text { antigen synthesis; endothelial } \\
\text { cell tube formation; leukocyte-synovial fibroblast } \\
\text { proliferation/adhesion; thymocyte maturation (T cell } \\
\text { receptor signaling/apoptosis) }\end{array}$ & [33-36] \\
\hline & FUT2 & leftH and $\mathrm{ABO}$ antigen synthesis & [37-40] \\
\hline \multirow{6}{*}{$\begin{array}{l}\alpha(1,3) \\
\alpha(1,4)\end{array}$} & FUT3 & $\mathrm{Le}^{\mathrm{a}}, \mathrm{Le}^{\mathrm{b}}, \mathrm{Le}^{\mathrm{x}}$, and sialyl-Le ${ }^{\mathrm{x}}\left(\mathrm{sLe}^{\mathrm{x}}\right)$ antigen synthesis & {$[31,41]$} \\
\hline & FUT4/5 & $\begin{array}{l}\text { Sialylated precursor selectin ligands (leukocyte biology); } \\
\mathrm{Le}^{\mathrm{a}}, \mathrm{Le}^{\mathrm{b}}, \mathrm{Le}^{\mathrm{x}}, \text { and sialyl-Le }\left(\mathrm{sLe}^{\mathrm{x}}\right) \text { antigen synthesis }\end{array}$ & {$[28,30,31,42-44]$} \\
\hline & FUT6 & $\operatorname{Le}^{\mathrm{x}}$ and sLe $\mathrm{x}^{\mathrm{x}}$ antigen synthesis & {$[28,31,45]$} \\
\hline & FUT7 & $\begin{array}{l}\text { Sialylated precursor selectin ligand synthesis (leukocyte } \\
\text { biology) }\end{array}$ & {$[1,31,46]$} \\
\hline & FUT9 & Le $^{\mathrm{x}}$ antigen synthesis & [31] \\
\hline & FUT10/11 & $\mathrm{Le}^{\mathrm{x}}$ and $\mathrm{sLe} \mathrm{x}^{\mathrm{x}}$ & {$[47,48]$} \\
\hline$\alpha(1,6)$ & FUT8 & TGF $\beta R$; EGFR; METR; E-cadherin, T-cell receptor & $\begin{array}{l}{[3,6,11,27,31,49-} \\
52]\end{array}$ \\
\hline O-fucosylation & POFUT1/2 & $\begin{array}{l}\text { Epidermal Growth Factor-like and Thrombospondin } \\
\text { Type } 1 \text { repeats of proteins }\end{array}$ & [19-21] \\
\hline
\end{tabular}

\section{Serum Fucose and Fucosylated Glycoconjugates}

Suboptimal diagnostic modalities represent an ongoing clinical challenge, hampering timely and efficient detection and treatment of cancer until it has progressed to advanced stages. The development of innovative early detection approaches is crucial for improving survival probability and the quality of life for cancer patients. Recently, the profiling of cancer patient sera for altered glycosylation states/levels of secreted proteins has emerged as a promising new diagnostic approach. Methods of detection have included high performance liquid chromatography (HPLC), liquid chromatography (LC), mass spectrometry (MS), matrix assisted laser desorption/ionization (MALDI), or combinations therein. In Table 3, we summarize findings from studies comparing serum fucose and fucosylated glycan profiles from healthy individuals vs. breast, oral/head and neck, HCC, ovarian, CRC, pancreatic, lung and prostate cancer patients. Several of these studies suggest diagnostic potential for serum L-fucose levels, which have been found to be elevated in cancer patient sera in breast [53-55], oral/head and neck [56-61], HCC [62-65], CRC [66,67], and ovarian [55,68] cancer patients compared with healthy individuals. Specific fucosylated glycoconjugates have been found to also have potential diagnostic utility. For example, fucosylated haptoglobin correlates with poorer survival probability, reduced responsiveness to therapy, and increased metastatic burden in breast [31], HCC [69-71], ovarian [31,55,72], CRC [67], pancreatic [73], and lung [31,74] cancer patients. Similar to haptoglobin, levels of serum fucosylated $\alpha$-fetoprotein are also increased in HCC patients have been reported to correlate with poor survival outcomes, increased disease recurrence, and portal vein thrombosis [31,75].

Table 3. Altered serum fucosylation profiles in cancer patients.

\begin{tabular}{clc}
\hline Cancer Type & \multicolumn{1}{c}{ Changes in Serum Fucosylation } & Refs \\
\hline & $\bullet$ Increased free L-fucose & {$[53,54]$} \\
Breast & $\bullet$ Increased serum FUT activity & {$[76]$} \\
& $\bullet$ Increased fucosylated haptoglobin & {$[77]$} \\
& $\bullet \alpha(1,3)$ fucosylation is increased in cancer patients & {$[54,55]$} \\
\hline Oral/Head \& Neck & $\bullet$ Increased free L-fucose & {$[56-61]$} \\
\hline
\end{tabular}


Table 3. Cont.

\begin{tabular}{clc}
\hline Cancer Type & \multicolumn{1}{c}{ Changes in Serum Fucosylation } & Refs \\
\hline \multirow{2}{*}{ Liver } & - Increased free L-fucose & {$[62,63]$} \\
& - Increased fucosylated haptoglobin & {$[69-71,78]$} \\
& - Core fucosylation of haptoglobin is increased in cancer patients & {$[69]$} \\
& - Increased fucosylated $\alpha$-fetoglobin in serum of cancer patients & {$[3,31,75]$} \\
\hline & - Increased free L-fucose & {$[68]$} \\
- FUT3 found to be circulating in serum & {$[55]$} \\
Ovarian & - Increased levels of fucosylated proteins in cancer patients & {$[79]$} \\
& - Increased fucosylated haptoglobin & {$[31,55,72]$} \\
\hline \multirow{2}{*}{ Prostate } & - Increased levels of fucosylated proteins in cancer patients & {$[80]$} \\
& - PSA from patient serum is $\alpha(1,2)$ fucosylated & {$[81]$} \\
& - PSA from patient serum is $\alpha(1,6)$ fucosylated & {$[82]$} \\
& - Core fucosylation of PSA in urine decreases as disease progresses & {$[83]$} \\
\hline & - Increased free L-fucose & {$[66]$} \\
Colorectal & - Increased serum FUT activity & {$[4]$} \\
& - Increased fucosylated haptoglobin & {$[67]$} \\
& - $\alpha(1,3)$ fucosylation is increased in cancer patients & {$[67]$} \\
\hline Pancreatic & - Increased fucosylated haptoglobin & {$[73]$} \\
\hline
\end{tabular}

Importantly, specific cancer types, such as lung cancer, can be further segregated into subgroups by fucosylation status. For example, a MALDI-MS comparison of the sera from former and current smokers with non-small cell lung carcinoma (NSCLC) revealed that fucosylated glycans were increased in current smokers [84]. Notably, serum fucose/FUT activity has been reported to associate with prognosis/therapeutic responsiveness in some cancers. Breast cancer and CRC patients undergoing chemotherapy or surgical resection, respectively, exhibit reduced serum FUT activity after therapy, suggesting (i) that serum FUT activity predominantly originates from the tumors, and (ii), that serum FUT activity/fucosylation levels might reflect therapeutic responsiveness [4,76]. Consistent with this notion, serum levels of $\alpha(1,3)$ fucosylation in breast and ovarian cancer patients are elevated during tumor progression but are significantly reduced in patients who responded to chemotherapy [55].

Despite growing evidence that aberrant fucosylation correlates with staging in several cancer types, the nature of correlative vs. causative relationship between differences fucose linkages on serum glycoconjugates and cancer is poorly understood. For example, whereas the $\alpha(1,2)$-fucosylated serum species of prostate specific antigen (PSA) has been reported to exhibit stronger correlation with the presence of prostate cancer than total PSA, the $\alpha(1,6)$-fucosylated species correlates with metastasis [81-83,85]. Increased serum $\alpha(1,3)$-fucosylated sLe ${ }^{\mathrm{x}}$ antigen or $\alpha(1,6)$-fucosylated haptoglobin levels are associated with the presence of breast cancer or HCC, respectively $[54,70]$. Similarly, core fucosylated $\alpha$-fetoprotein has exhibited clinical utility in the early detection of HCC [3]. Interestingly, increased serum levels of fucosylated E-cadherin also correlates with stageindependent poor prognosis in lung cancer patients [51]. The diversity of linkage types and the largely unknown/uncharacterized fucosylated proteins and their functional contributions to cancer represent an area of opportunity for important and clinically relevant basic research.

\section{5. $\alpha(1,2)$ Fucosylation}

$\alpha(1,2)$ fucosylation exhibits seemingly divergent effects in cancer progression. Whereas it is tumor suppressive and reduced in melanoma [14,15,86-88], oral/head and neck [16], gastric [89], and HCC $[17,63]$ carcinomas, it is tumor-promoting and increased in bladder, breast, epidermoid, ovarian, and prostate tumors (Table 4) [33,90-93]. 
Table 4. Alterations and roles of $\alpha(1,2)$ fucosylation in tumors.

\begin{tabular}{|c|c|c|}
\hline Cancer Type & Alterations and Roles of $\alpha(1,2)$ Fucosylation & Refs \\
\hline Melanoma & $\begin{array}{l}\text { - } \alpha(1,2) \text { fucosylation inhibits tumor formation } \\
\text { - } 25 \% \text { of melanoma cell lines lack FUT1 expression } \\
\text { - FUT1 expression is decreased in tumors } \\
\text { - } \alpha(1,2) \text { fucosylation inhibits invadopodia \& invasion }\end{array}$ & $\begin{array}{c}{[14,15,87]} \\
{[11,94]} \\
{[14,95]} \\
{[87]}\end{array}$ \\
\hline Oral/Head \& Neck & $\begin{array}{l}\text { - } \alpha(1,2) \text { fucosylation inhibits tumor formation } \\
\text { - FUT1 expression is decreased in tumors } \\
\text { - } \alpha(1,2) \text { fucosylation high in tumors, lost at invading front }\end{array}$ & [16] \\
\hline Gastric & - $\alpha(1,2)$ fucosylation inhibits tumor formation & [89] \\
\hline Hepatocellular & $\begin{array}{l}\text { - } \alpha(1,2) \text { fucosylation inhibits tumor formation } \\
\text { - FUT1 expression is decreased in tumors }\end{array}$ & $\begin{array}{l}{[17,63]} \\
{[63]}\end{array}$ \\
\hline Ovarian & - $\alpha(1,2)$ fucosylation is increased by FUT1 upregulation & [96] \\
\hline Prostate & - $\alpha(1,2)$ fucosylation is increased by FUT1 upregulation & {$[81,85]$} \\
\hline Colorectal & $\begin{array}{l}\text { - } \alpha(1,2) \text { fucosylation increased in tumor tissues } \\
\text { - FUT1 expression attenuates adhesion and metastasis to the liver }\end{array}$ & {$[15,97-99]$} \\
\hline Pancreatic & $\begin{array}{l}\text { - } \alpha(1,2) \text { fucosylation is decreased in primary tumor tissues. } \\
\text { - FUT1 expression decreases metastatic adhesion }\end{array}$ & $\begin{array}{l}{[86,100-102]} \\
{[86]}\end{array}$ \\
\hline Breast & $\begin{array}{l}\text { - FUT1 mRNA is upregulated in adriamycin-resistant cells } \\
\text { - } \alpha(1,2) \text { fucosylation regulates autophagic flux }\end{array}$ & [92] \\
\hline Bladder & - $\alpha(1,2)$ fucosylation promotes cell adhesion & [93] \\
\hline Epidermoid & - $\alpha(1,2)$ fucosylation promotes cell proliferation & [90] \\
\hline
\end{tabular}

To date, $\alpha(1,2)$ fucosylation levels in cancer correlate with, and appear most likely regulated by, FUT1. The downregulation of FUT1, and consequently of $\alpha(1,2)$ fucosylation, has been attributed, at least in pancreatic cancer, to constitutive Hif1 $\alpha$-mediated transcriptional suppression, suggesting that in pancreatic cancer, hypoxia suppresses cell surface $\alpha(1,2)$ fucosylation, which promotes cancer cell motility and migration [101]. We recently reported that FUT1-mediated $\alpha(1,2)$ fucosylation abrogates invadopodia formation/ECM degradation and inhibits melanoma cell motility and tumor growth/metastasis in vivo $[14,87,88]$. These findings indicate that reduced FUT1 expression, and consequently, loss of $\alpha(1,2)$ fucosylation, promotes melanoma invasiveness/progression by enhancing invadopodia formation. The cell-based studies and in vivo xenograft models are consistent with findings from OSCC and HCC cells, supporting the roles of FUT1 and $\alpha(1,2)$ fucosylation in suppressing tumor progression and metastasis.

In contrast to melanoma, OSCC, and HCC, $\alpha(1,2)$ fucosylation is increased and elicits tumorpromoting effects in bladder, breast, epidermoid, ovarian, and prostate tumors, where it stimulates cellular proliferation, adhesion, invasion, metastasis, and drug resistance [11,33,91,93,103-106]. In ovarian [96] and prostate [85] tumors, increased $\alpha(1,2)$ fucosylation is linked to upregulation of FUT1 and promotes TGF $\beta$ signaling, cellular proliferation, and impairs apoptosis $[36,96,107]$. The precise molecular mechanisms remain unclear and likely require functional players beyond TGF $\beta$ RI/II. For example, in ovarian cancer, FUT1 promotes upregulation of MUC1, which stimulates proliferation, invasion, and metastasis [108]. In breast cancer, FUT1 promotes mTOR activity and lysosomal and autophagosomal dynamics via $\alpha(1,2)$ fucosylation of lysosome-associated membrane protein (LAMP) 1 [91].

However, $\alpha(1,2)$ fucosylation/FUT1 can also elicit seemingly divergent tumor-suppressive or tumor-promoting effects in cancer. For example, the ectopic expression of FUT1 in CRC cells perturbs their stromal interactions in vitro and impairs metastatic capacity in vivo $[17,97,109]$. Although $\alpha(1,2)$ fucosylation thus appears to be tumor-promoting in CRC, it has also been reported to be upregulated in patient-derived CRC tissues compared to normal tissues [97-99]. This dichotomy might be due 
tumor stage-specific functions/effects of FUT1, where loss of $\alpha(1,2)$ fucosylation is required before metastatic cells can adhere to new sites. The expression of FUT1 is decreased in pancreatic primary tumor cell lines compared to normal tissue, but the ectopic re-expression of FUT1 in the metastatic pancreatic cancer cells inhibits metastasis by enhancing the cell surface abundance of $\mathrm{Le}^{\mathrm{y}}$ and inhibiting E-selectin-mediated adhesion $[17,86]$. Together, these studies suggest that $\alpha(1,2)$ fucosylation plays crucial tumor suppressive roles during initiation and that its loss promotes metastatic progression.

Given the remarkable heterogeneity between cancer types, further studies will be crucial for elucidating the specific fucosylated proteins (e.g., key upstream receptors, stromal-interacting membrane proteins etc.) that mediate the divergent effects elicited by $\alpha(1,2)$ fucosylation to promote/suppress tumor progression. Furthermore, the identification of cancer signaling pathways that are significantly altered by $\alpha(1,2)$ fucosylation, together with the identification of key fucosylated proteins mediators, might yield useful insights for the stratification/therapeutic intervention for subsets of cancer.

\section{6. $\alpha(1,3)$ and $\alpha(1,4)$ Branching}

Compared to $\alpha(1,2)$ fucosylation, more consistent pathological effects have generally been reported for $\alpha(1,3 / 4)$ fucosylation across different cancer types. $\alpha(1,3 / 4)$ fucosylation is upregulated in breast [110-112], liver [63,113], ovarian [114,115], CRC [97], pancreatic [100,116,117], gastric [118,119], lung [120], and prostate [121-123] cancers compared with normal tissue counterparts (Table 4). Several of the above-mentioned studies focused on a single or a few FUTs using RT-PCR, Le antigen IHC staining, ELISAs with corresponding lectins, and/or lectin microarrays and have reported that increased levels $\alpha(1,3 / 4)$ fucosylation contribute to metastasis. As detailed in Table 5, several FUTs can mediate $\alpha(1,3 / 4)$ fucosylation that confers tumorigenic properties.

Table 5. Alterations of $\alpha(1,3 / 4)$ fucosylation tumors.

\begin{tabular}{|c|c|c|}
\hline Cancer Type & Changes in $\alpha(1,3 / 4)$ Fucosylation & Reference \\
\hline Breast & \multirow{10}{*}{ - $\alpha(1,3 / 4)$ fucosylation upregulated in tumor tissue } & [110-112] \\
\hline Melanoma & & [124] \\
\hline Oral/Head \& Neck & & [125] \\
\hline Liver & & {$[63,113]$} \\
\hline Ovarian & & {$[114,115]$} \\
\hline Prostate & & [121-123] \\
\hline Colorectal & & [97] \\
\hline Pancreatic & & {$[100,116,117]$} \\
\hline Gastric & & {$[118,119]$} \\
\hline Lung & & [120] \\
\hline
\end{tabular}

Of the FUTs that mediate $\alpha(1,3)$ - and/or $\alpha(1,4)$-fucosylation, FUT3, 4, 6, and 7 are most frequently reported as upregulated across cancer types. Of the other FUTs, FUT5, FUT10, and FUT11 have been reported to contribute to cell adhesion and metastasis through the generation of $s L e^{\mathrm{x}}$ and $s L e^{\mathrm{a}}$ antigens [111,119]. In breast cancer cells, increased FUT4, 5, 6, 10 and 11 levels correlate with increased migration and proliferation and the increased expression of angiogenesis-related genes including VEGFA, VEGFR1, VEGFR2, and FGF2. Pharmacological inhibition of fucosylation using 2-fluorofucose, a fucosyltransferase inhibitor, blocks breast cancer cell migration and proliferation and is associated with attenuated RTK, MAPK and p38 signaling [111]. In ovarian cancer cells, FUT3, 4, and 9 promote motility by mediating the $\alpha(1,3)$ and $\alpha(1,4)$ fucosylation of specific Le antigens $[115,126]$.

FUT3 has generally been reported as a crucial mediator of tumor-promoting signaling. In CRC, FUT3 is required for TGF $\beta$ signaling, as knockdown of FUT3 inhibits fucosylation of TGF $\beta$ R1 and 
attenuates Smad2 signaling, consequently decreasing migration and invasion [127]. Loss of FUT3 across several tumor cell lines/types has been reported to decrease migration [119,127], invasion [127], TGF $\beta$ signaling [127], interaction with E-selectin [116,119,123,125], metastatic potential in vivo [116], and drug resistance [128]. In contrast, the ectopic overexpression of FUT3 amplifies sLe ${ }^{\mathrm{x}}$ levels $[122,124]$ and promotes cellular adhesion [122], tumor growth [122], and metastasis [122,124].

FUT4 is upregulated in several cancer types and has been shown to promote proliferation [129], invasion [125,130], tumor growth $[129,130]$, and drug resistance $[128,131]$. Consistent with protumorigenic function, loss of FUT4 in melanoma cells inhibits proliferation and tumor growth and is associated with reduced EGFR and MAPK signaling [129]. FUT4 is also implicated in drug resistance. For example, the ectopic expression of FUT4 in multidrug-resistant HCC cells enhances activation of pro-survival signaling including the PI3K/AKT pathway [131]. However, FUT4 has been reported to elicit anti-tumor effects. For example, the ectopic expression of FUT4 in A549 lung cancer cells suppresses EGFR signaling and invasive capacity [6]. It is possible that opposing tumorigenic vs. tumor-suppressive functions of FUT4 are elicited in stage- and context-specific manners. Recently, FUT4 expression was shown to be regulated by several miRNAs, which are downregulated in breast cancer tissues $[92,130,132]$, highlighting one mechanism by which FUT4 fucosylation is enhanced in breast cancer tissues. It is possible that other FUTs are subject to similar mechanisms of regulation.

FUT6 has also been reported to elicit similar pro-tumorigenic roles as FUT4 in various cancer types $[113,125,127,131,133]$. Like FUT3, FUT6 also fucosylates sLe ${ }^{\mathrm{x}}$ antigens, amplifying cellular adhesion and promoting metastasis, with concomitant upregulation of pro-tumorigenic TGF $\beta$ signaling [127].

FUT7 is upregulated in HCC [134-136], lung, [137] and prostate [133] carcinomas and elicits tumor-promoting effects. The ectopic expression of FUT7 promotes adhesion, colony formation, invasion, proliferation and survival [108], and migration [133,134,138], whereas its knockdown reverts these effects. Although the effects appear to require p38 and JNK, the direct underlying mechanisms are currently not known [136].

In summary, $\alpha(1,3 / 4)$ fucosylation, which is mediated by FUTs 3-7 and 9-11, is generally increased and elicits tumor-promoting effects in the cancers discussed above. This has been evidenced by the fact that these FUTs mediate the production of several Lewis antigens, including SLe $^{\mathrm{x}}$, which have been demonstrated to promote metastatic capacity. Specifically, sLe ${ }^{\mathrm{x}}$, which is upregulated in cancer cells, can promote metastasis by binding to E-selectin, which is expressed on endothelial cells. This interaction can slow the rolling speed of cancer cells along the vascular endothelium under shear forces, enhancing the ability of circulating tumor cells to extravasate from the vasculature into surrounding tissues $[116,119,121,123,134]$. In addition to increasing sLe ${ }^{x}$ levels, several $\alpha(1,3 / 4)$ FUTs can alter cell surface receptor (e.g., growth factor receptor)-mediated signaling, which is important for tumor development. Future comprehensive studies are required to dissect the probable complex functional redundancy among the $\alpha(1,3 / 4)$ FUTs to determine their specific cancer type- and stage-specific functional contributions. Ultimately, the elucidation of the pathological contributions of $\alpha(1,3 / 4)$ FUTs is important for developing novel therapeutic targets and strategies.

\section{7. $\alpha(1,6)$ Fucosylation}

FUT8 is the only fucosyltransferase known, to date, to conjugate fucose onto core GlcNAc residues of N-glycans. Extensive studies in melanoma [95], breast [139], liver [63,95,140], ovarian [68], cervical [141] CRC [97,142,143], pancreatic [117], gastrointestinal [89,144-146], thyroid papillary [147-149], and lung [52,150-152] cancers have highlighted core fucosylation and specific core fucosylated proteins as prognostic serum and tissue biomarkers (Table 6).

Generally, core fucosylation has been reported to be increased in tumor tissues compared to normal tissues, suggesting tumor-promoting functions. Several studies have reported that the silencing of FUT8 in cultured prostate, melanoma, lung, breast, and HCC cancer cells that express high levels 
of FUT8 inhibits invasion [95,140], migration [140,153], proliferation [52,140], colony formation [52], tumor growth $[5,50,95]$, and metastasis $[5,95]$.

Table 6. Alterations of core fucosylation in tumors.

\begin{tabular}{|c|c|c|}
\hline Cancer Type & Changes in $\alpha(1,6)$ Fucosylation & Reference \\
\hline Breast & \multirow{8}{*}{ - Core fucosylation increased in tumor tissue } & {$[139,154]$} \\
\hline Melanoma & & [95] \\
\hline Liver & & {$[11,63,140,155]$} \\
\hline Ovarian & & {$[11,68,141,156]$} \\
\hline Cervical & & [141] \\
\hline Colorectal & & {$[11,97,142,143]$} \\
\hline Pancreatic & & [117] \\
\hline Lung & & {$[52,150-152]$} \\
\hline Gastric & $\begin{array}{l}\text { - Core fucosylation increased in tumor tissue } \\
\text { - Core fucosylation decreased in tumor tissue }\end{array}$ & $\begin{array}{c}{[89,145]} \\
{[144,146]}\end{array}$ \\
\hline Prostate & - Core fucosylation increased in castrate resistant tissue & [157] \\
\hline
\end{tabular}

The specific functional effects elicited by core fucosylation are attributed to its regulation to a number of important growth factor signaling pathways including those mediated by TGF $\beta[5,158]$, EGFR [6,50,158,159], VEGFR [158], and c-Met [50] (Figure 4). Fucosylation also impacts the activity/ signaling of other plasma membrane proteins including $\beta 1$-integrin [159], $\beta$-catenin $[155,160]$, and E-cadherin [52,160]. Knockdown or inhibition of FUT8/suppression of core fucosylation attenuates these signaling pathways, suppressing cancer growth/survival in vitro models of lung cancer and HCC. $[6,50]$ In addition, FUT8 knockdown or lectin blockade (i.e., incubation of cells with unconjugated LCA lectin, which binds/blocks $\alpha(1,6)$ linkages) inhibits breast cancer stemness and EMT [154].

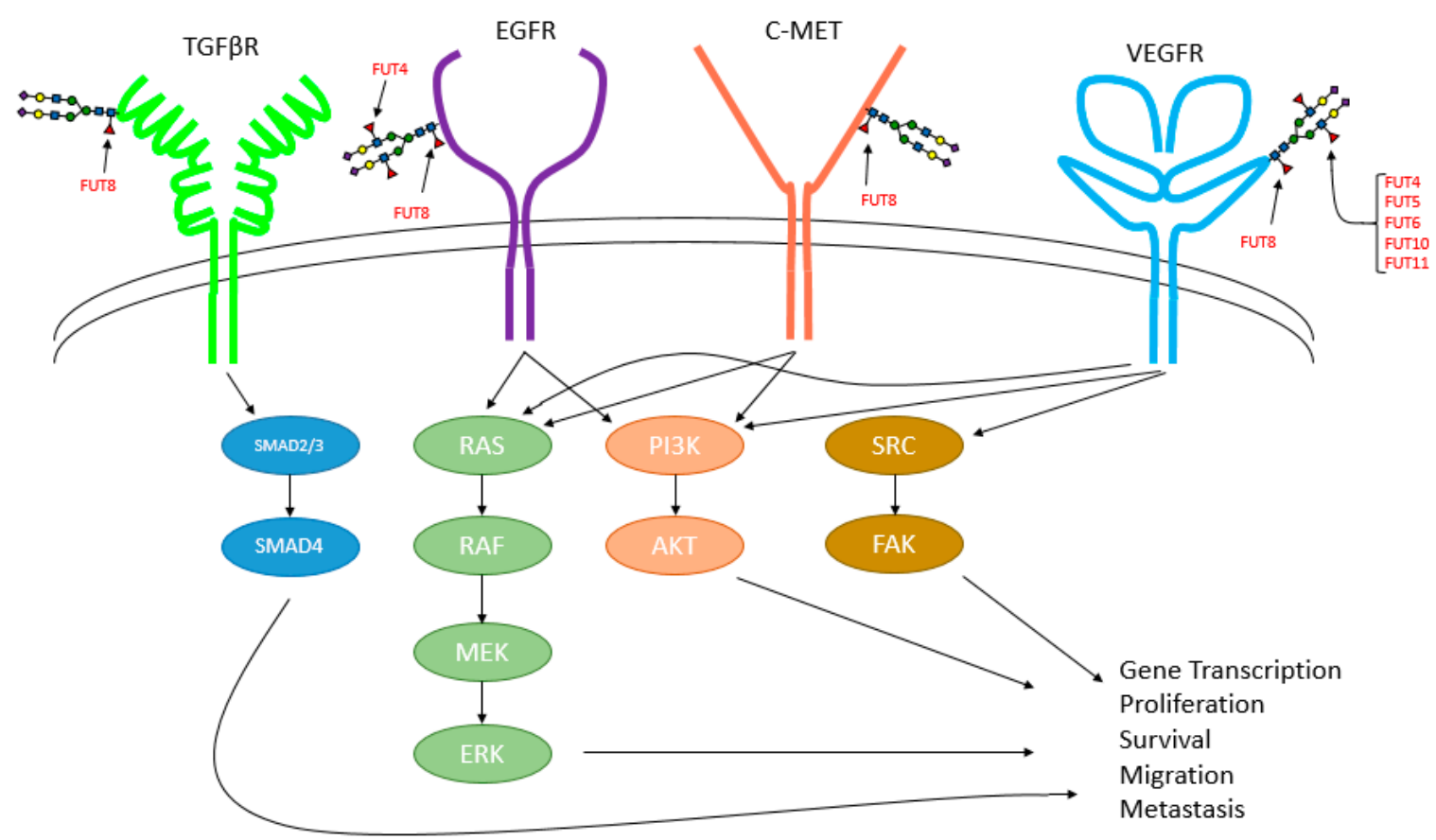

Figure 4. Growth factor signaling pathways known to be regulated by fucosylation. 
However, gastrointestinal cancer studies have reported discrepant findings, where three studies have reported reduced core fucosylation in tumors [144,146,161], whereas two reported increased core fucosylation in tumors $[89,145]$. Interestingly, a number of studies have reported low levels of core fucosylation in gastric cancer cells [146,162], giant lung cancer cells [163], and HCC cells [164] and that the overexpression of FUT8 in those cancer cells suppresses proliferation, tumor formation, and metastasis. The mechanism(s) underlying these differences, as well as the pathological contexts and functional roles remain unclear, in large part because our understanding of how FUT8 is regulated remains limited.

At the transcriptional level, FUT8 has been reported to be transcriptionally activated by p53 [165]. As p53 is often inactivated in cancer, aberrant upregulation of FUT8 might be attributed to the activity of other as-of-yet undefined transcription factors. Post-transcriptionally, FUT8 has been reported to be regulated by miR-122 and miR-34, which bind to the $3^{\prime}$ UTR of FUT8 mRNA transcripts, inhibiting its expression, and consequently, reducing core fucosylation [166]. The roles of these and other miRNAs in the control of FUT expression and fucosylation in cancer remain to be determined. Furthermore, the contributions of these FUT8-regulating mechanisms likely vary by pathological context, resulting in diversity of core fucosylation across cancers.

The divergent regulation of FUT8 and resulting core fucosylation levels can be regulated in stageand other clinical context-specific manners. The stage-wise importance and contributions of core fucosylation to tumorigenesis has been clearly illustrated in a mouse model of HCC development, where FUT8 activity is required for the development of well-vascularized tumors, whereas knockout of FUT8 completely abolishes tumor formation [50]. In the context of cancer cell responses to therapies, FUT8 has been reported to promote drug resistance. FUT8 expression is increased in drug resistant HCC cells, and its knockdown attenuates Akt-mediated survival signaling [131]. In prostate cancer, FUT8 is upregulated in castration-resistant cells and can mediate the survival and proliferation of non-resistant cells in castrate-(hormone-depleted) conditions [157]. Interestingly, a commonly administered opioid analgesic for cancer patients, fentanyl, was reported to promote breast cancer progression by upregulating FUT8 and enhancing $\alpha(1,6)$ fucosylation, highlighting the unanticipated and confounding effects that therapeutic clinical agents have on fucosylation [154]. These findings prompt the question of whether pain management agents inadvertently promote core fucosylation-mediated cancer progression. How fucosylation and which FUTs are affected by opioids and other supportive agents represents an important and understudied area. Importantly, as FUT8 is the only known fucosyltransferase to mediate core fucosylation, it might prove to be a valuable target for cancer therapy.

\section{O-Fucosylation}

O-fucosylation has been extensively studied for its biological functions in protein folding, secretion [167,168], and in the regulation of Notch signaling [169-173]. Given these biological roles, O-fucosylation is anticipated to impact several functional hallmarks and signaling pathways in cancer that have yet to be defined. Currently, limited data supports this notion. in vitro studies have revealed that aberrant expression of POFUT1 promotes tumorigenic behavior in HCC lines by altering Notch signaling, and in addition, upregulated POFUT1 expression in human HCC tissue specimens correlates with poor overall survival outcomes and increased recurrence rates [174]. In contrast, increased POFUT1 expression in breast cancers is intriguingly associated with longer relapse free and overall survival [175]. The divergent effects of O-fucosylation between different cancer types highlights the need for further studies to elucidate the underlying mechanistic differences.

\section{Potential Therapeutic Utility}

In regard to therapeutic approaches and clinical utility, L-fucose, fucose-containing extracts, inhibitors of fucosylation, and fucosylated liposomes have been investigated as potential therapeutic agents for various cancer types. The administration of L-fucose has been shown to inhibit cell growth 
in vitro [176] and tumor growth in vivo in breast cancer [177], melanoma [14], lung cancer [4], and Ehrlich carcinoma [178]. As the aberrant expression of certain FUTs appear to elicit tumorigenic effects in tumor cells, it is not immediately clear how the administration of L-fucose inhibits tumor growth and progression. One possible explanation is that the administration of L-fucose increases GDP-fucose substrate availability, boosting the levels of fucosylated glycans with tumor-suppressive properties compared to those with tumorigenic properties. Another possibility is that the administration of L-fucose stimulates anti-tumor immunity $[14,179]$. Further studies of these phenomena are expected to lead to advances in fucosylation-based therapeutics or dietary interventions for cancer that might slow/block tumor progression or elicit preventative or therapeutic effects.

Currently, L-fucose is relatively expensive and inefficient to purify, which represents a prohibitive factor when considering new treatment options [4]. Furthermore, high levels of L-fucose occur naturally in various species of seaweeds, which can be readily supplemented into current diets. Seaweed-derived L-fucose extracts (known as fucoidan) have been analyzed and shown to elicit anti-tumorigenic responses in breast cancer [180-182] and CRC [181,183,184]. Several studies have reported tumor suppressive properties of fucoidan [185-193]. Fucoidan treatment is associated with reduced VEGF and Hif1 $\alpha$ expression, reduced activation of ERK, inhibited angiogenesis, and attenuated lung cancer cell proliferation, migration, and tumor volume [185]. Fucoidan treatment can also block the angiogenesis-promoting abilities as well as the viability of anaplastic thyroid cancer cells [192]. In lung cancer xenograft models, fucoidan significantly attenuates tumor growth by enhancing ER stress-induced apoptosis. Whereas fucoidan does not affect the proliferation of OSCC cells, it inhibits their invasive capacity, and further, modulates their interactions with macrophages [186]. Treatment of melanoma cells with fucoidan is associated with reduced tyrosinase activity and melanin content, as well as decreased viability [188]. In combination with the ERBB inhibitor lapatinib, fucoidan was reported to enhance melanoma cell killing without adverse effects in mouse models [191]. Fucoidan also elicits dose-dependent effects in prostate cancers cells, reducing cell viability/proliferation, migration, tube formation, tumor volume, and activation of the JAK/STAT pathway. [189] Primary effusion lymphoma cells treated with fucoidan exhibit inhibited proliferation, tumor burden, and enhanced apoptosis as evidenced by increased expression of cleaved capsase-3, -8, -9, and cleaved PARP [190]. Although the use of fucoidan appears beneficial in cancer treatment, further studies, such as those elucidating bioavailability, pharmacokinetics, and pharmacodynamics are required to delineate how and when they should be administered to patients for maximum benefit.

Within the past decade, inhibitors of fucosylation have emerged as potential therapeutic agents under investigation for their ability to inhibit cancer progression. Fluorinated and alkynated fucose analogs have been developed to suppress the synthesis of GDP-fucose, thereby preventing FUTs from fucosylating glycans $[111,159,194-196]$. The treatment of breast cancer cell lines with 2-fluorofucose inhibits sLe ${ }^{\mathrm{x}}$ antigen expression, leading to reduced adhesion but not viability [111]. The treatment of HCC cell lines with 2-fluorofucose inhibits core fucosylation, cell proliferation, migration, and tumor formation [159]. Recently, 6-alkyl-fucose was shown to be a more potent than 2-flurofucose in inhibiting fucosylation and viability in HCC cells [196]. Further studies aimed at determining how fucosylation profiles change or are restored in cancer cells after treatment with fucosylation inhibitors or with L-fucose/fucoidan are expected to clarify how they can be used to help suppress or prevent which types of cancer.

Immunotherapies and combination treatments are becoming leading topics in cancer treatment. $\mathrm{T}$ cells are one of the cytotoxic populations of the adaptive immune system that require core fucosylation of the $\mathrm{T}$ cell receptor to be activated in disease [197-200]. One of the more extensively investigated immunotherapies is immune checkpoint blockade, specifically antibodies that target and disrupt the interaction between programmed death 1 (PD-1) and its cognate ligand (PD-L1). Interestingly, a defucosylated antibody engineered to disrupt the PD-1/PD-L1 interaction by binding to PD-L1 was recently reported to more effectively induce $\mathrm{T}$ cell response and cytotoxicity against cancer cells than fucosylated counterparts [201]. Briefly, PD-L1 on the cell surface of tumor cells interacts with PD-1 on 
T cells to induce exhaustion, thus impairing the cytotoxic effects of T cells, [202] leading to immune evasion and continued tumor growth. PD-L1 on tumor cells is glycosylated, which contributes to its stabilization at the cell surface [203]. Similar to the glycosylation of PD-L1 in tumor cells, the fucosylation of PD-1 was recently reported to promote its stabilization and presentation at the surface of T cells. Murine T cells inhibited for core fucosylation by Fut 8 knockout or pharmacological inhibition (2-fluorofucose) exhibited reduced PD-1 expression and were more cytotoxic and effective at killing melanoma and lung cancer cells [204]. Investigations examining the clinical efficacy of fucosylation inhibitors targeting FUT8 in human T cells will need to be conducted.

\section{Conclusions and Closing Remarks}

Cancer development and tumor progression require pathogenic alterations to normal cellular biology. Increasing research efforts, including those investigating the roles of fucosylation in cancer, are focusing on determining how aberrant glycosylation mechanistically contributes to tumorigenesis and metastatic progression (Table 7).

Table 7. Summary of studies that have manipulated FUTs and documented biological outcomes in tumor cell lines.

\begin{tabular}{|c|c|c|}
\hline Cancer Type & Results of FUT Manipulation in Cell Lines & Reference \\
\hline Breast & $\begin{array}{l}\text { - FUT4 overexpression promoted invasion \& tumor growth } \\
\text { - FUT8 knockdown inhibited tumor growth \& metastasis } \\
\text { - FUT8 overexpression promoted EMT and invasion }\end{array}$ & $\begin{array}{l}{[130]} \\
{[5]} \\
{[5]}\end{array}$ \\
\hline Melanoma & $\begin{array}{l}\text { - FUT1 overexpression inhibited metastasis } \\
\text { - FUT1 overexpression inhibited invadopodia \& invasion } \\
\text { - FUT4 knockdown inhibited proliferation \& tumor growth } \\
\text { - FUT8 knockdown decreased invasion, tumor growth, \& metastasis }\end{array}$ & $\begin{array}{l}{[15]} \\
{[87]} \\
{[129]} \\
{[95]}\end{array}$ \\
\hline Oral/Head \& Neck & $\begin{array}{l}\text { - FUT1 overexpression suppressed cell growth \& invasion; knockdown increased cell } \\
\text { growth \&invasion } \\
\text { - FUT3 overexpression promoted invasion } \\
\text { - FUT6 overexpression enhanced adhesion \& invasion }\end{array}$ & $\begin{array}{l}{[16]} \\
{[125]} \\
{[125]}\end{array}$ \\
\hline Liver & $\begin{array}{l}\text { - FUT1 overexpression suppressed adhesion } \\
\text { - FUT6 overexpression increased proliferation, colony formation, \& tumor growth } \\
\text { - FUT4, 6, \& } 8 \text { overexpression amplified drug resistance } \\
\text { - FUT4, 6, \& } 8 \text { knockdown suppressed drug resistance and inhibited tumor growth } \\
\text { - FUT7 silencing decreased adhesion, migration, \& invasion } \\
\text { - FUT7 overexpression amplified proliferation } \\
\text { - FUT8 knockdown inhibited invasion, migration, \& proliferation } \\
\text { - FUT8 overexpression suppressed proliferation, tumor formation, \& metastasis }\end{array}$ & $\begin{array}{l}{[17]} \\
{[113]} \\
{[131]} \\
{[131]} \\
{[134]} \\
{[138]} \\
{[140]} \\
{[164]}\end{array}$ \\
\hline Ovarian & $\begin{array}{l}\text { - FUT1 overexpression increased proliferation adhesion, invasion, metastasis \& resistance } \\
\text { - FUT1 overexpression increased colony formation \& proliferation }\end{array}$ & $\begin{array}{c}{[108,205]} \\
{[103]}\end{array}$ \\
\hline Prostate & $\begin{array}{l}\text { - FUT3 overexpression amplified adhesion } \\
\text { - FUT6 overexpression increased migration \& metastasis } \\
\text { - FUT7 overexpression enhanced adhesion } \\
\text { - FUT8 knockdown decreased migration } \\
\text { - FUT8 overexpression increased motility }\end{array}$ & $\begin{array}{l}{[133]} \\
{[133]} \\
{[133]} \\
{[153]} \\
{[153]}\end{array}$ \\
\hline Colorectal & $\begin{array}{l}\text { - FUT1 overexpression suppressed adhesion } \\
\text { - FUT1 overexpression inhibited metastasis } \\
\text { - FUT3 \& } 6 \text { knockdown decreased adhesion, invasion, \& migration } \\
\text { - FUT5/6 knockdown inhibited migration and proliferation }\end{array}$ & $\begin{array}{l}{[97]} \\
{[109]} \\
{[127]} \\
{[206]}\end{array}$ \\
\hline Pancreatic & $\begin{array}{l}\text { - FUT1 overexpression suppressed adhesion and metastasis } \\
\text { - FUT3 knockdown decreased migration, adhesion, and metastatic colonization }\end{array}$ & $\begin{array}{c}{[86]} \\
{[116,207]}\end{array}$ \\
\hline Gastric & $\begin{array}{l}\text { - FUT3 knockdown decreases migration } \\
\text { - FUT5 knockdown inhibited adhesion \& migration } \\
\text { - FUT8 overexpression suppressed proliferation, tumor formation, \& metastasis }\end{array}$ & $\begin{array}{l}{[119]} \\
{[119]} \\
{[146]}\end{array}$ \\
\hline Lung & $\begin{array}{l}\text { - FUT4 overexpression promoted EMT } \\
\text { - FUT7 overexpression increased adhesion, colony formation, invasion, \& migration } \\
\text { - FUT8 knockdown decreased proliferation \& colony formation } \\
\text { - FUT8 overexpression suppressed proliferation, tumor formation, \& metastasis }\end{array}$ & $\begin{array}{c}{[208]} \\
{[137]} \\
{[52]} \\
{[163]}\end{array}$ \\
\hline
\end{tabular}


Although trends in fucosylated glycan structures have been identified among several cancer types (Table 8), many questions remain regarding the differential roles of such types of fucosylation in cancer pathogenesis. Specific fucosylated proteins and the signaling mechanisms that they regulate are just beginning to be elucidated.

Table 8. Visual summary of fucosylation changes of the branching types in cancer tissues vs. normal tissues. $\uparrow$-increased; $\downarrow$-decreased; $\uparrow \rightarrow \downarrow$-increased in primary, decreased in metastasis.

\begin{tabular}{cccc}
\hline Cancer Type & $\alpha \mathbf{( 1 , 2 )}$ & $\boldsymbol{\alpha ( 1 , 3 / 4 )}$ & $\boldsymbol{\alpha ( 1 , 6 )}$ \\
\hline Breast & - & $\uparrow$ & $\uparrow$ \\
\hline Melanoma & $\downarrow$ & $\uparrow$ & $\uparrow$ \\
\hline Oral/Head \& Neck & $\downarrow$ & $\uparrow$ & - \\
\hline Liver & $\downarrow$ & $\uparrow$ & $\uparrow$ \\
\hline Ovarian & $\uparrow$ & $\uparrow$ & $\uparrow$ \\
\hline Prostate & $\uparrow$ & $\uparrow$ & $\uparrow$ \\
\hline Colorectal & $\downarrow / \uparrow$ & $\uparrow$ & $\uparrow$ \\
\hline Pancreatic & $\uparrow \rightarrow \downarrow$ & $\uparrow$ & $\uparrow$ \\
\hline Gastric & - & $\uparrow$ & $\downarrow / \uparrow$ \\
\hline Lung & - & $\uparrow$ & $\downarrow / \uparrow$ \\
\hline
\end{tabular}

Few studies have investigated the functional contributions of cell surface fucosylation during different stages of tumorigenesis, from invasion into local tissues, basement membrane, and the lymphatics and vasculature during metastatic progression $[5,87,88,151,159]$. Expanding and determining how such mechanistic insights can be used to improve diagnostic or treatment strategies for cancer are expected to improve patient outcomes.

Our understanding of the importance of fucosylation in cancer has undergone significant expansion since studies in the early 1960s. Despite the current complexity of fucosylation and cancer progression, increasing studies are actively elucidating the underlying mechanisms and applications of L-fucose, fucose analogs, and specific aspects of fucosylation to enhance the detection of and therapeutic interventions for multiple cancer types, ultimately aiming to improve clinical outcomes for patients.

Author Contributions: T.S.K. researched and wrote the manuscript. S.Y. and E.L. provided editorial guidance and wrote portions of the manuscript.

Funding: The authors would like to acknowledge funding from the Elsa U. Pardee Foundation and the National Cancer Institute (NCI) (R01 CA175741, R01 CA233844) to S.Y. and from the Harry J. Lloyd Charitable Trust Foundation (melanoma biology research grant) and NCI (5R00CA172705-05 and R01 CA241599-01) to E.L.

Acknowledgments: The authors would like to acknowledge the University of South Florida Cancer Biology Graduate Program, the Department of Cellular and Molecular Physiology at Penn State College of Medicine, and the Department of Tumor Biology at H. Lee Moffitt Cancer Center and Research Institute for support.

Conflicts of Interest: All authors have no financial or non-financial competing interests.

\section{Abbreviations}

CRC colorectal carcinoma

EGF epidermal growth factor

ELISA enzyme-linked immunosorbent assay

EMT epithelial-mesenchymal transition

FGF fibroblast growth factor

FUK fucokinase

FUT fucosyltransferase

FX NADP(H)-binding epimerase-reductase

GlcNAc N'-acetylglucosamine 


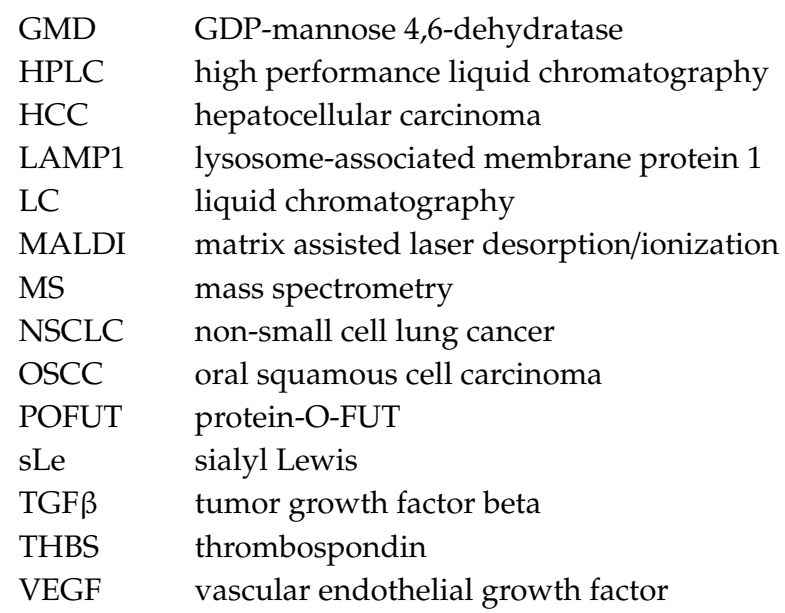

\section{References}

1. Becker, D.J.; Lowe, J.B. Fucose: Biosynthesis and biological function in mammals. Glycobiology 2003, 13, 41R-53R. [CrossRef] [PubMed]

2. Chan, J.Y.; Nwokoro, N.A.; Schachter, H. L-Fucose Metabolism in Mammals. J. Biol. Chem. 1979, 254, 7060-7068. [PubMed]

3. Wang, X.; Taniguchi, N. Core Fucosylation of N-Linked Glycan for Fine-Tuning TGF b Receptor Function. Glycosci. Biol. Med. 2015, 2014, 991-997.

4. Vanhooren, P.T.; Vandamme, E.J. L-Fucose: Occurence, physiological role, chemical, enzymatic and microbial synthesis. J. Chem. Technol. Biotechnol. 1999, 74, 479-497. [CrossRef]

5. Tu, C.F.; Wu, M.Y.; Lin, Y.C.; Kannagi, R.; Yang, R.B. FUT8 promotes breast cancer cell invasiveness by remodeling TGF- $\beta$ receptor core fucosylation. Breast Cancer Res. 2017, 19, 111. [CrossRef] [PubMed]

6. Liu, Y.-C.; Yen, H.-Y.; Chen, C.-Y.; Chen, C.-H.; Cheng, P.-F.; Juan, Y.-H.; Chen, C.-H.; Khoo, K.-H.; Yu, C.-J.; Yang, P.-C.; et al. Sialylation and fucosylation of epidermal growth factor receptor suppress its dimerization and activation in lung cancer cells. Proc. Natl. Acad. Sci. USA 2011, 108, 11332-11337. [CrossRef] [PubMed]

7. Ezawa, I.; Sawai, Y.; Kawase, T.; Okabe, A.; Tsutsumi, S.; Ichikawa, H.; Kobayashi, Y.; Tashiro, H.; Kondo, T.; Semba, K.; et al. A novel p53 target gene FUCA1 encodes a fucosidase and regulates growth and survival of cancer cells. Cancer Sci. 2016, 107, 734-745. [CrossRef]

8. Listinsky, J.J.; Listinsky, C.M.; Alapati, V.; Siegal, G.P. Cell surface fucose ablation as a therapeutic strategy for malignant neoplasms. Adv. Anat. Pathol. 2001, 8, 330-337. [CrossRef]

9. Hanahan, D.; Weinberg, R.A. Hallmarks of Cancer: The Next Generation. Cell 2011, 144, 646-674. [CrossRef]

10. Vajaria, B.N.; Patel, P.S. Glycosylation: A hallmark of cancer? Glycoconj. J. 2017, 34, 147-156. [CrossRef]

11. Christiansen, M.N.; Chik, J.; Lete, L.Y.; Anugraham, M.; Abrahams, J.L.; Packer, N.H. Cell surface protein glycosylation in cancer. Proteomics 2014, 14, 525-546. [CrossRef]

12. Shan, M.; Yang, D.; Dou, H.; Zhang, L. Fucosylation in cancer biology and its clinical applications. In Progress in Molecular Biology and Translational Science; Zhang, L., Ed.; Elsevier: Cambridge, MA, USA, 2019; Volume 162, pp. 93-119.

13. Eccles, M.R.; Chatterjee, A.; Rodger, E.J. Identifying drivers of metastasis; towards a systematic approach. Transl. Cancer Res. 2017, 6, S1273-S1276. [CrossRef]

14. Lau, E.; Feng, Y.; Claps, G.; Fukuda, M.N.; Perlina, A.; Donn, D.; Jilaveanu, L.; Kluger, H.; Freeze, H.H.; Ronai, Z.A. The transcription factor ATF2 promotes melanoma metastasis by suppressing protein fucosylation. Sci. Signal. 2015, 8, 1-12. [CrossRef]

15. Gorelik, E.; Xu, F.; Henion, T.; Anaraki, F.; Galili, U. Reduction of metastatic properties of BL6 melanoma cells expressing terminal fucose $\alpha 1$-2-galactose after $\alpha 1,2$-fucosyltransferase cDNA transfection. Cancer Res. $1997,57,332-336$.

16. Hotta, H.; Hamamura, K.; Yamashita, K.; Shibuya, H.; Tokuda, N.; Hashimoto, N.; Furukawa, K.; Yamamoto, N.; Hattori, H.; Toyokuni, S.; et al. Lewis y antigen is expressed in oral squamous cell carcinoma cell lines and tissues, but disappears in the invasive regions leading to the enhanced malignant properties irrespective of sialyl-Lewis x. Glycoconj. J. 2013, 30, 585-597. [CrossRef] 
17. Mathieu, S.; Prorok, M.; Benoliel, A.-M.; Uch, R.; Langlet, C.; Bongrand, P.; Gerolami, R.; El-Battari, A.l. Transgene Expression of $\alpha(1,2)$-Fucosyltransferase-I (FUT1) in Tumor Cells Selectively Inhibits Sialyl- Lewis $\mathrm{x}$ Expression and Binding to E-Selectin without Affecting Synthesis of Sialyl-Lewis a or Binding to P-Selectin. Am. J. Pathol. 2004, 164, 371-383. [CrossRef]

18. Wieses, T.J.; Dunlap, J.A.; Yorekg, M.A. L-Fucose Is Accumulated via a Specific Transport System in Eukaryotic Cells. Journal of Biological Chemistry. J. Biol. Chem. 1994, 269, 22705-22711.

19. McMillan, B.J.; Zimmetrman, B.; Egan, E.D.; Lofgren, M.; Xu, X.; Hesser, A.; Blacklow, S.C. Structure of human POFUT1, its requirement in ligand-independent oncogenic Notch signaling, and functional effects of Dowling-Degos mutations. Glycobiology 2017, 27, 777-786. [CrossRef]

20. Holdener, B.C.; Haltiwanger, R.S. Protein O-fucosylation: Structure and function. Curr. Opin. Struct. Biol. 2019, 56, 78-86. [CrossRef]

21. Lira-Navarrete, E.; Valero-González, J.; Villanueva, R.; Martínez-Júlvez, M.; Tejero, T.; Merino, P.; Panjikar, S.; Hurtado-Guerrero, R. Structural insights into the mechanism of protein O-fucosylation. PLoS ONE 2011, 6, 1-14. [CrossRef]

22. Ng, B.G.; Rosenfeld, J.A.; Emrick, L.; Jain, M.; Burrage, L.C.; Lee, B.; Craigen, W.J.; Bearden, D.R.; Graham, B.H.; Freeze, H.H. Pathogenic Variants in Fucokinase Cause a Congenital Disorder of Glycosylation. Am. J. Hum. Genet. 2018, 103, 1030-1037. [CrossRef]

23. Teas, J.; Irhimeh, M.R. Melanoma and brown seaweed: An integrative hypothesis. J. Appl. Phycol. 2017, 29, 941-948. [CrossRef]

24. Smith, P.L.; Myers, J.T.; Rogers, C.E.; Zhou, L.; Petryniak, B.; Becker, D.J.; Homeister, J.W.; Lowe, J.B. Conditional control of selectin ligand expression and global fucosylation events in mice with a targeted mutation at the FX locus. J. Cell Biol. 2002, 158, 801-815. [CrossRef]

25. Prestegard, J.H.; Liu, J.; Widmalm, G. Oligosaccharides and Polysaccharides. In Essentials of Glycobiology; Cold Spring Harbor Laboratory Press: Cold Spring Harbor, NY, USA, 2017.

26. Mcnaught, A.D. Nomenclature of Carbohydrates. Pure Appl. Chem. 1996, 297, 1-91. [CrossRef]

27. Liang, W.; Mao, S.; Sun, S.; Li, M.; Li, Z.; Yu, R.; Ma, T.; Gu, J.; Zhang, J.; Taniguchi, N.; et al. Core fucosylation of the $\mathrm{T}$ cell receptor is required for T cell activation. Front. Immunol. 2018, 9, 1-14. [CrossRef]

28. Tu, Z.; Lin, Y.-N.; Lin, C.-H. Development of fucosyltransferase and fucosidase inhibitors. Chem. Soc. Rev. 2013, 42, 4459-4475. [CrossRef]

29. Ewald, D.R.; Sumner, S.C.J. Blood type biochemistry and human disease. Wiley Interdiscip. Rev. Syst. Biol. Med. 2016, 8, 517-535. [CrossRef]

30. de Vries, T.; Knegtel, R.M.A.; Holmes, E.H.; Macher, B.A. Fucosyltransferases: Structure/function studies. Glycobiology 2001, 11, 119R-128R. [CrossRef]

31. Miyoshi, E.; Moriwaki, K.; Nakagawa, T. Biological Function of Fucosylation in Cancer Biology. J. Biochem. 2008, 143, 725-729. [CrossRef]

32. Blanas, A.; Sahasrabudhe, N.M.; Rodríguez, E.; van Kooyk, Y.; van Vliet, S.J. Fucosylated Antigens in Cancer: An Alliance toward Tumor Progression, Metastasis, and Resistance to Chemotherapy. Front. Oncol. 2018, 8, 1-14. [CrossRef]

33. Isozaki, T.; Ruth, J.H.; A Amin, M.; Campbell, P.L.; Tsou, P.-S.; Ha, C.M.; Haines, G.K.; Edhayan, G.; Koch, A.E. Fucosyltransferase 1 mediates angiogenesis, cell adhesion and rheumatoid arthritis synovial tissue fibroblast proliferation. Arthritis Res. Ther. 2014, 16, R28. [CrossRef]

34. Moore, G.T.C.; Brown, S.J.; Winterhalter, A.C.; Lust, M.; Salvaris, E.J.; Selan, C.; Nandurkar, H.H.; Desmond, P.V.; Cowan, P.J.; D'Apice, A.J.; et al. Glycosylation changes in hFUT1 transgenic mice increase TCR signaling and apoptosis resulting in thymocyte maturation arrest. Mol. Immunol. 2008, 45, 2401-2410. [CrossRef]

35. Larsen, R.D.; Ernst, L.K.; Nair, R.P.; Lowe, J.B. Molecular cloning, sequence, and expression of a human GDP-L-fucose:beta-D-galactoside 2-alpha-L-fucosyltransferase cDNA that can form the H blood group antigen. Proc. Natl. Acad. Sci. USA 1990, 87, 6674-6678. [CrossRef]

36. Gao, N.; Liu, J.; Liu, D.; Hao, Y.; Yan, L.; Ma, Y.; Zhuang, H.; Hu, Z.; Gao, J.; Yang, Z.; et al. C-Jun transcriptionally regulates alpha 1, 2-fucosyltransferase 1 (FUT1) in ovarian cancer. Biochimie 2014, 107, 286-292. [CrossRef] 
37. Weiss, F.U.; Schurmann, C.; Guenther, A.; Ernst, F.; Teumer, A.; Mayerle, J.; Simon, P.; Völzke, H.; Radke, D.; Greinacher, A.; et al. Fucosyltransferase 2 (FUT2) non-secretor status and blood group B are associated with elevated serum lipase activity in asymptomatic subjects, and an increased risk for chronic pancreatitis: A genetic association study. Gut 2015, 64, 646-656. [CrossRef]

38. McGovern, D.P.B.; Jones, M.R.; Taylor, K.D.; Marciante, K.; Yan, X.; Dubinsky, M.; Ippoliti, A.; Vasiliauskas, E.; Berel, D.; Derkowski, C.; et al. Fucosyltransferase 2 (FUT2) non-secretor status is associated with Crohn's disease. Hum. Mol. Genet. 2010, 19, 3468-3476. [CrossRef]

39. Henry, S.; Mollicone, R.; Lowe, J.B.; Samuelsson, B.; Larson, G. A Second Nonsecretor Allel of the Blood Group $\alpha(1,2)$ Fucosyl-transferase Gene (FUT2). Int. J. Transferase Med. 1996, 70, 21-25.

40. Rouquier, S.; Lowe, J.B.; Kelly, R.J.; Fertitta, A.L.; Lennon, G.G.; Giorgi, D. Molecular Cloning of a Human Genomic Region Containing the H Blood Group $\alpha(1,2)$ Fucosyltransferase Gene and Two H Locus-related DNA Restraiction Fragments. J. Biol. Chem. 1995, 270, 4632-4639. [CrossRef]

41. Kukowska-Latallo, J.F.; Larsen, R.D.; Nair, R.P.; Lowe, J.B. A cloned human cDNA determines expression of a mouse stage-specific embryonic antigen and the Lewis blood group $\alpha(1,3 / 1,4)$ fucosyltransferase. Genes Dev. 1990, 4, 1288-1303. [CrossRef]

42. Weston, B.W.; Nair, R.P.; Larsen, R.D.; Lowe, J.B. Isolation of a Novel Human a(1,3)Fucosyltransferase Gene and Molecular Comparison to the Human Lewis Blood Group a $(1,3 / 1,4)$ Fucosyltransferase Gene. J. Biol. Chem. 1992, 267, 4152-4160.

43. Gersten, K.M.; Natsuka, S.; Trinchera, M.; Petryniak, B.; Kelly, R.J.; Hiraiwa, N.; Jenkins, N.A.; Gilbert, D.J.; Copeland, N.G.; Lowe, J.B. Molecular Cloning, Expression, Chromosomal Assignment, and Tissue-specific Expression of a Murine-(1,3)-Fucosyltransferase Locus Corresponding to the Human ELAM-1 Ligand Fucosyl Transferase. J. Biol. Chem. 1995, 270, 25047-25056. [CrossRef]

44. Lowe, J.B.; Kukowska-Latallo, J.F.; Nair, R.P.; Larsen, R.D.; Marks, R.M.; A Macher, B.; Kelly, R.J.; Ernst, L.K. Molecular cloning of a human fucosyltransferase gene that determines expression of the Lewis $\mathrm{x}$ and VIM-2 epitopes but not ELAM-1-dependent cell adhesion. J. Biol. Chem. 1991, 266, 17467-17477.

45. Weston, B.W.; Smith, P.L.; Kelly, R.J.; Lowenii, J.B. Molecular cloning of a fourth member of a human $\alpha(1,3)$ fucosyltransferase gene family. J. Biol. Chem. 1992, 267, 24576-24584.

46. Natsuka, S.; Gersten, K.M.; Zenita, K.; Kannagi, R.; Lowe, J.B. Molecular cloning of a cDNA encoding a novel human leukocyte $\alpha-1,3$-fucosyltransferase capable of synthesizing the sialyl Lewis $\mathrm{x}$ determinant. J. Biol. Chem. 1994, 269, 16789-16794.

47. Patnaik, S.K. Characterization of Fut10 and Fut11, Putative Alpha 1-3/4 Fucosyltransferase Genes Important for Vertebrate Development. Nat. Preced. 2007. [CrossRef]

48. Mollicone, R.; Moore, S.E.H.; Bovin, N.; Garcia-Rosasco, M.; Candelier, J.-J.; Martinez-Duncker, I.; Oriol, R. Activity, splice variants, conserved peptide motifs, and phylogeny of two New $\alpha 1,3$-fucosyltransferase families (FUT10 and FUT11). J. Biol. Chem. 2009, 284, 4723-4738. [CrossRef]

49. Lowe, J.B.; Marth, J.D. A Genetic Approach to Mammalian Glycan Function. Annu. Rev. Biochem. 2003, 72, 643-691. [CrossRef]

50. Wang, Y.; Fukuda, T.; Isaji, T.; Lu, J.; Im, S.; Hang, Q.; Gu, W.; Hou, S.; Ohtsubo, K.; Gu, J. Loss of $\alpha 1,6$-fucosyltransferase inhibits chemical-induced hepatocellular carcinoma and tumorigenesis by down-regulating several cell signaling pathways. FASEB J. 2015, 29, 3217-3227. [CrossRef]

51. Wen, C.L.; Chen, K.-Y.; Chen, C.-T.; Chuang, J.-G.; Yang, P.-C.; Chow, L.-P. Development of an AlphaLISA assay to quantify serum core-fucosylated E-cadherin as a metastatic lung adenocarcinoma biomarker. J. Proteomics 2012, 75, 3963-3976. [CrossRef]

52. Geng, F.; Zhi Shi, B.; Feng Yuan, Y.; Zhong, X.W. The expression of core fucosylated E-cadherin in cancer cells and lung cancer patients: Prognostic implications. Cell Res. 2004, 14, 423-433. [CrossRef]

53. Rosato, F.E.; Seltzer, M.; Mullen, J.; Rosato, E.F. Serum Fucose in the Diagnosis of Breast Cancer. Cancer 1971, 28, 1575-1579. [CrossRef]

54. Abd Hamid, U.M.; Royle, L.; Saldova, R.; Radcliffe, C.M.; Harvey, D.J.; Storr, S.J.; Pardo, M.; Antrobus, R.; Chapman, C.J.; Zitzmann, N.; et al. A strategy to reveal potential glycan markers from serum glycoproteins associated with breast cancer progression. Glycobiology 2008, 18, 1105-1118. [CrossRef]

55. Thompson, S.; Cantwell, B.M.J.; Matta, K.L.; Turner, G.A. Parallel changes in the blood levels of abnormally-fucosylated haptoglobin and alpha 1,3 fucosyltransferase in relationship to tumour burden: More evidence for a disturbance of fucose metabolism in cancer. Cancer Lett. 1992, 65, 115-121. [CrossRef] 
56. Ghosh, M.; Raghavan, M.R.V.; Nayak, B.R.; Bailoor, D.N. Evaluation of Serum Fucose Level in Patients with Oral Cancer. Oral Surg. Oral Med. Oral Pathol. 1988, 65, 418-420. [CrossRef]

57. Shah, M.; Telang, S.; Raval, G.; Shah, P.; Patel, P.S. Serum fucosylation changes in oral cancer and oral precancerous conditions: $\alpha$-L-fucosidase as a marker. Cancer 2008, 113, 336-346. [CrossRef]

58. Chinnannavar, S.; Ashok, L.; Vidya, K.C.; Setty, S.M.K.; Narasimha, G.E.; Garg, R. Evaluation of serum sialic acid, fucose levels and their ratio in oral squamous cell carcinoma. J. Int. Soc. Prev. Community Dent. 2015, 5, 446. [CrossRef]

59. Kumar, S.; Saxena, M.; Srinivas, K.; Singh, V. Fucose: A biomarker in grading of oral cancer. Natl. J. Maxillofac. Surg. 2015, 6, 176.

60. Rai, N.P.; Anekar, J.; Shivaraja, S.Y.; Divakar, D.D.; Al Kheraif, A.A.; Ramakrishnaiah, R.; Sebastian, R.; Raj, A.; Al-Hazmi, A.; Mustafa, H.M. Comparison of serum fucose levels in leukoplakia and oral cancer patients. Asian Pac. J. Cancer Prev. 2015, 16, 7497-7500. [CrossRef]

61. Rathan Shetty, S.K.; Kumar Bhandary, S.; Kali, A. Significance of serum L-fucose glycoprotein as cancer biomarker in head and neck malignancies without distant metastasis. J. Clin. Diagn. Res. 2013, 7, 2818-2820.

62. Block, T.M.; Comunale, M.A.; Lowman, M.; Steel, L.F.; Romano, P.R.; Fimmel, C.; Tennant, B.C.; London, W.T.; Evans, A.A.; Blumberg, B.S.; et al. Use of targeted glycoproteomics to identify serum glycoproteins that correlate with liver cancer in woodchucks and humans. Proc. Natl. Acad. Sci. USA 2005, 102, 779-784. [CrossRef]

63. Hutchinson, W.L.; Du, M.-Q.; Johnson, P.J.; Williams, R. Fucosyltransferases: Differential plasma and tissue alterations in hepatocellular carcinoma and cirrhosis. Hepatology 1991, 13, 683-688. [CrossRef]

64. Thompson, S.; Turner, G.A. Elevated levels of abnormally-fucosylated haptoglobins in cancer sera. Br. J. Cancer 1987, 56, 605-610. [CrossRef]

65. Thompson, S.; Cantwell, B.M.J.; Cornell, C.; Turner, G.A. Abnormally-fucosylated haptoglobin: A cancer marker for tumour burden but not gross liver metastasis. Br. J. Cancer 1991, 64, 386-390. [CrossRef]

66. Fernández-Rodríguez, J.; De La Cadena, M.P.; Martínez-Zorzano, V.S.; Rodríguez-Berrocal, F.J. Fucose levels in sera and in tumours of colorectal adenocarcinoma patients. Cancer Lett. 1997, 121, 147-153. [CrossRef]

67. Takeda, Y.; Moriwaki, K.; Murata, K.; Miyoshi, E. Fucosylated haptoglobin is a novel type of cancer biomarker linked to the prognosis after an operation in colorectal cancer. Cancer 2012, 118, 3036-3043. [CrossRef]

68. Takahashi, T.; Ikeda, Y.; Miyoshi, E.; Yaginuma, Y.; Ishikawa, M.; Taniguchi, N. $\alpha 1,6$ Fucosyltransferase is Highly and Specifically Expressed in Human Ovarian Serous Adenocarcimomas. Int. J. Cancer 2000, 88, 914-919. [CrossRef]

69. Miyoshi, E.; Moriwaki, K.; Terao, N.; Tan, C.-C.; Terao, M.; Nakagawa, T.; Matsumoto, H.; Shinzaki, S.; Kamada, Y. Fucosylation Is a Promising Target for Cancer Diagnosis and Therapy. Biomolecules 2012, 2, $34-45$. [CrossRef]

70. Zhu, J.; Lin, Z.; Wu, J.; Yin, H.; Dai, J.; Feng, Z.; Marrero, J.; Lubman, D.M. Analysis of serum haptoglobin fucosylation in hepatocellular carcinoma and liver cirrhosis of different etiologies. J. Proteome Res. 2014, 13, 2986-2997. [CrossRef]

71. Zhang, Y.; Zhu, J.; Yin, H.; Marrero, J.; Zhang, X.-X.; Lubman, D.M. ESI-LC-MS Method for Haptoglobin Fucosylation Analysis in Hepatocellular Carcinoma and Liver Cirrhosis. J. Proteome Res. 2015, 14, 5388-5395. [CrossRef]

72. Thompson, S.; Dargan, E.; Turner, G.A. Increased fucosylation and other carbohydrate changes in haptoglobin in ovarian cancer. Cancer Lett. 1992, 66, 43-48. [CrossRef]

73. Miyoshi, E.; Nakano, M. Fucosylated haptoglobin is a novel marker for pancreatic cancer: Detailed analyses of oligosaccharide structures. Proteomics 2008, 8, 3257-3262. [CrossRef]

74. Ferens-Sieczkowska, M.; Kratz, E.M.; Kossowska, B.; Passocz-Muszynska, E.; Jankowska, R. Comparison of Haptoglobin and Alpha 1 -Acid Glycoprotein Glycosylation in the Sera of Small Cell and Non-Small Cell Lung Cancer Patients. Postepy Hig. Med. Dosw. 2013, 67, 828-836. [CrossRef]

75. Yamashita, F.; Tanaka, M.; Satomura, S.; Tanikawa, K. Prognostic significance of Lens culinaris agglutinin A-reactive alpha-fetoprotein in small hepatocellular carcinomas. Gastroenterology 1996, 111, 996-1001. [CrossRef]

76. Bauer, C.H.; Reutter, W.G.; Erhart, K.P.; Kottgen, E.; Gerok, W. Decrease of Human Serum Fucosyltransferase as an Indicator of Successful Tumor Therapy. Science 1978, 201, 1232-1233. [CrossRef] 
77. Turner, G.A. A potential reporter molecule for glycosylation changes in disease. Adv. Exp. Med. Biol. 1995, 376, 231-238.

78. Narisada, M.; Kawamoto, S.; Kuwamoto, K.; Moriwaki, K.; Nakagawa, T.; Matsumoto, H.; Asahi, M.; Koyama, N.; Miyoshi, E. Identification of an inducible factor secreted by pancreatic cancer cell lines that stimulates the production of fucosylated haptoglobin in hepatoma cells. Biochem. Biophys. Res. Commun. 2008, 377, 792-796. [CrossRef]

79. Thakkar, V.; Patel, P.; Prajapati, N.; Kaur, R.; Nandave, M. Serum levels of glycoproteins are elevated in patients with ovarian cancer. Indian J. Clin. Biochem. 2014, 29, 345-350. [CrossRef]

80. Saldova, R.; Fan, Y.; Fitzpatrick, J.M.; Watson, R.W.G.; Rudd, P.M. Core fucosylation and $\alpha 2-3$ sialylation in serum $\mathrm{N}$-glycome is significantly increased in prostate cancer comparing to benign prostate hyperplasia. Glycobiology 2011, 21, 195-205. [CrossRef]

81. Kosanović, M.M.; Janković, M.M. Sialylation and fucosylation of cancer-associated prostate specific antigen. J. BUON 2005, 10, 247-250.

82. Kekki, H.; Peltola, M.; van Vliet, S.; Bangma, C.; van Kooyk, Y.; Pettersson, K. Improved cancer specificity in PSA assay using Aleuria aurantia lectin coated Eu-nanoparticles for detection. Clin. Biochem. 2017, 50, 54-61. [CrossRef]

83. Fujita, K.; Hayashi, T.; Matsuzaki, K.; Nakata, W.; Masuda, M.; Kawashima, A.; Ujike, T.; Nagahara, A.; Tsuchiya, M.; Kobayashi, Y.; et al. Decreased fucosylated PSA as a urinary marker for high Gleason score prostate cancer. Oncotarget 2016, 7, 56643-56649. [CrossRef]

84. Vasseur, J.A.; Goetz, J.A.; Alley, W.R.; Novotny, M.V. Smoking and lung cancer-induced changes in N-glycosylation of blood serum proteins. Glycobiology 2012, 22, 1684-1708. [CrossRef]

85. Fukushima, K.; Satoh, T.; Baba, S.; Yamashita, K. $\alpha 1$,2-Fucosylated and $\beta$-N-acetylgalactosaminylated prostate-specific antigen as an efficient marker of prostatic cancer. Glycobiology 2009, 20, 452-460. [CrossRef]

86. Aubert, M.; Panicot, L.; Crotte, C.; Gibier, P.; Lombardo, D.; Sadoulet, M.O.; Mas, E. Restoration of alpha(1,2) fucosyltransferase activity decreases adhesive and metastatic properties of human pancreatic cancer cells. Cancer Res. 2000, 60, 1449-1456.

87. Keeley, T.; Lin, S.; Lester, D.K.; Lau, E.K.; Yang, S. The fucose salvage pathway inhibits invadopodia formation and extracellular matrix degradation in melanoma cells. PLoS ONE 2018, 13, e0199128. [CrossRef]

88. Keeley, T.S. Investigating the Roles of Fucosylation and Calcium Signaling in Melanoma Invasion; University of South Florida: Tampa, FL, USA, 2018.

89. Chandrasekaran, E.V.; Xue, J.; Piskorz, C.; Locke, R.D.; Tóth, K.; Slocum, H.K.; Matta, K.L. Potential tumor markers for human gastric cancer: An elevation of glycan:sulfotransferases and a concomitant loss of alpha1,2-fucosyltransferase activities. J. Cancer Res. Clin. Oncol. 2007, 133, 599-611. [CrossRef]

90. Palumberi, D.; Aldi, S.; Ermini, L.; Ziche, M.; Finetti, F.; Donnini, S.; Rosati, F. RNA-mediated gene silencing of FUT1 and FUT2 influences expression and activities of bovine and human fucosylated nucleolin and inhibits cell adhesion and proliferation. J. Cell. Biochem. 2010, 111, 229-238. [CrossRef]

91. Tan, K.-P.; Ho, M.-Y.; Cho, H.-C.; Yu, J.; Hung, J.-T.; Yu, A.L.-T. Fucosylation of LAMP-1 and LAMP-2 by FUT1 correlates with lysosomal positioning and autophagic flux of breast cancer cells. Cell Death Dis. 2016, 7, e2347. [CrossRef]

92. Feng, X.; Zhao, L.; Gao, S.; Song, X.; Dong, W.; Zhao, Y.; Zhou, H.; Cheng, L.; Miao, X.; Jia, L. Increased fucosylation has a pivotal role in multidrug resistance of breast cancer cells through miR-224-3p targeting FUT4. Gene 2016, 578, 232-241. [CrossRef]

93. Lu, Y.; Chen, C.; Chu, C.; Lu, J.; Wang, B.; Chen, C.; Huang, M.; Lin, T.; Pan, C.; Chen, S.A.; et al. Calreticulin activates $\beta 1$ integrin via fucosylation by fucosyltransferase 1 in $\mathrm{J} 82$ human bladder cancer cells. Biochem. J. 2014, 460, 69-78. [CrossRef]

94. Laidler, P.; Lityńska, A.; Hoja-Łukowicz, D.; Łabedz, M.; Przybyło, M.; Ciołczyk-Wierzbicka, D.; Pocheć, E.; Trebacz, E.; Kremser, E. Characterization of glycosylation and adherent properties of melanoma cell lines. Cancer Immunol. Immunother. 2006, 55, 112-118. [CrossRef]

95. Agrawal, P.; Fontanals-Cirera, B.; Sokolova, E.; Jacob, S.; Vaiana, C.A.; Argibay, D.; Davalos, V.; McDermott, M.; Nayak, S.; Darvishian, F.; et al. A Systems Biology Approach Identifies FUT8 as a Driver of Melanoma Metastasis. Cancer Cell 2017, 31, 804-819. [CrossRef]

96. Hao, Y.; Zhu, L.; Yan, L.; Liu, J.; Liu, D.; Gao, N.; Tan, M.; Gao, S.; Lin, B. C-Fos mediates $\alpha 1$, 2-fucosyltransferase 1 and Lewis y expression in response to TGF- $\beta 1$ in ovarian cancer. Oncol. Rep. 2017, 38, 3355-3366. 
97. Holst, S.; Wuhrer, M.; Rombouts, Y. Glycosylation characteristics of colorectal cancer. Adv. Cancer Res. 2015, 126, 203-256.

98. Misonou, Y.; Shida, K.; Korekane, H.; Seki, Y.; Noura, S.; Ohue, M.; Miyamoto, Y. Comprehensive clinico-glycomic study of 16 colorectal cancer specimens: Elucidation of aberrant glycosylation and its mechanistic causes in colorectal cancer cells. J. Proteome Res. 2009, 8, 2990-3005. [CrossRef]

99. Domino, S.E.; Karnak, D.M.; Hurd, E.A. Cell surface fucosylation does not affect development of colon tumors in mice with germline Smad3 mutation. Tumor Biol. 2007, 28, 77-83. [CrossRef]

100. Mas, E.; Pasqualini, E.; Caillol, N.; El Battari, A.; Crotte, C.; Lombardo, D.; Sadoulet, M.-O. Fucosyltransferase activities in human pancreatic tissue: Comparative study between cancer tissues and established tumoral cell lines. Glycobiology 1998, 8, 605-613. [CrossRef]

101. Belo, A.I.; Van Vliet, S.J.; Maus, A.; Laan, L.C.; Nauta, T.D.; Koolwijk, P.; Tefsen, B.; Van Die, I. Hypoxia inducible factor $1 \alpha$ down regulates cell surface expression of $\alpha 1$,2-fucosylated glycans in human pancreatic adenocarcinoma cells. FEBS Lett. 2015, 589, 2359-2366. [CrossRef]

102. Kim, Y.S.; Itzkowitz, S.H.; Yuan, M.; Chung, Y.; Satake, K.; Umeyama, K.; Hakomori, S. Lex and Ley Antigen Expression in Human Pancreatic Cancer. Cancer Res. 1988, 48, 475-482.

103. Liu, J.; Lin, B.; Hao, Y.; Li, Y.; Liu, J.; Cong, J.; Zhu, L.; Liu, Q.; Zhang, S. Lewis y antigen promotes the proliferation of ovarian carcinoma-derived RMG-I cells through the PI3K/Akt signaling pathway. J. Exp. Clin. Cancer Res. 2019, 28, 154. [CrossRef]

104. Li, F.; Lin, B.; Hao, Y.; Li, Y.; Liu, J.; Cong, J.; Zhu, L.; Liu, Q.; Zhang, S. Lewis Y promotes growth and adhesion of ovarian carcinoma-derived RMG-I cells by upregulating growth factors. Int. J. Mol. Sci. 2010, 11, 3748-3759. [CrossRef]

105. Gao, S.; Zhu, L.; Feng, H.; Hu, Z.; Jin, S.; Song, Z.; Liu, D.; Liu, J.; Hao, Y.; Li, X.; et al. Gene expression profile analysis in response to $\alpha 1$,2-fucosyl transferase (FUT1) gene transfection in epithelial ovarian carcinoma cells. Tumor Biol. 2016, 37, 12251-12262. [CrossRef]

106. Marker, P.C.; Stephan, J.-P.; Lee, J.; Bald, L.; Mather, J.P.; Cunha, G.R. Fucosyltransferase1 and H-type complex carbohydrates modulate epithelial cell proliferation during prostatic branching morphogenesis. Dev. Biol. 2001, 233, 95-108. [CrossRef]

107. Li, F.F.; Liu, J.J.; Liu, D.W.; Lin, B.; Hao, Y.Y.; Cong, J.P.; Zhu, L.C.; Gao, S.; Zhang, S.L.; Iwamori, M. Lewis Y regulates signaling molecules of the transforming growth factor $\beta$ pathway in ovarian carcinoma-derived RMG-I cells. Int. J. Oncol. 2012, 40, 1196-1202. [CrossRef]

108. Hou, R.; Jiang, L.; Liu, D.; Lin, B.; Hu, Z.; Gao, J.; Zhang, D.; Zhang, S.; Iwamori, M. Lewis(y) antigen promotes the progression of epithelial ovarian cancer by stimulating MUC1 expression. Int. J. Mol. Med. 2017, 40, 293-302. [CrossRef]

109. Mejías-Luque, R.; López-Ferrer, A.; Garrido, M.; Fabra, À.; de Bolós, C. Changes in the invasive and metastatic capacities of HT-29/M3 cells induced by the expression of fucosyltransferase 1. Cancer Sci. 2007, 98, 1000-1005. [CrossRef]

110. Yuan, K.; Kucik, D.; Singh, R.K.; Listinsky, C.M.; Listinsky, J.J.; Siegal, G.P. Alterations in human breast cancer adhesion-motility in response to changes in cell surface glycoproteins displaying alpha-L-fucose moieties. Int. J. Oncol. 2008, 32, 797-807.

111. Carrascal, M.A.; Silva, M.; Ramalho, J.S.; Pen, C.; Martins, M.; Pascoal, C.; Amaral, C.; Serrano, I.; Oliveira, M.J.; Sackstein, R.; et al. Inhibition of fucosylation in human invasive ductal carcinoma reduces E-selectin ligand expression, cell proliferation, and ERK1/2 and p38 MAPK activation. Mol. Oncol. 2018, 12, 579-593. [CrossRef]

112. Drake, P.M.; Schilling, B.; Niles, R.K.; Prakobphol, A.; Li, B.; Jung, K.; Cho, W.; Braten, M.; Inerowicz, H.D.; Williams, K.; et al. Lectin chromatography/mass spectrometry discovery workflow identifies putative biomarkers of aggressive breast cancers. J. Proteome Res. 2012, 11, 2508-2520. [CrossRef]

113. Guo, Q.; Guo, B.; Wang, Y.; Wu, J.; Jiang, W.; Zhao, S.; Qioa, S.; Wu, Y. Functional analysis of alpha1,3/4-fucosyltransferase VI in human hepatocellular carcinoma cells. Biochem. Biophys. Res. Commun. 2012, 417, 311-317. [CrossRef]

114. Sanders, D.S.A.; Milne, D.M.; Kerr, M.A. The expression of Lewisa and Lewisb antigens reflects changes in fucosylation between normal and neoplastic cervical squamous epithelium. J. Pathol. 1990, 162, $23-28$. [CrossRef] 
115. Escrevente, C.; Machado, E.; Brito, C.; A Reis, C.; Stoeck, A.; Runz, S.; Marmé, A.; Altevogt, P.; Costa, J. Different expression levels of alpha3/4 fucosyltransferases and Lewis determinants in ovarian carcinoma tissues and cell lines. Int. J. Oncol. 2006, 29, 557-566.

116. Aubert, M.; Panicot-Dubois, L.; Crotte, C.; Sbarra, V.; Lombardo, D.; Sadoulet, M.; Mas, E. Peritoneal colonization by human pancreatic cancer cells is inhibited by antisense FUT3 sequence. Int. J. Cancer 2000, 88, 558-565. [CrossRef]

117. Watanabe, K.; Ohta, M.; Yada, K.; Komori, Y.; Iwashita, Y.; Kashima, K.; Inomata, M. Fucosylation is associated with the malignant transformation of intraductal papillary mucinous neoplasms: A lectin microarray-based study. Surg. Today 2016, 46, 1217-1223. [CrossRef]

118. Aziz, F.; Gao, W.; Yan, Q. Fucosyltransferase-4 and Oligosaccharide Lewis Y Antigen as potentially Correlative Biomarkers of Helicobacter pylori CagA Associated Gastric Cancer. Pathol. Oncol. Res. 2017, 23, 173-179. [CrossRef]

119. Padró, M.; Cobler, L.; Garrido, M.; De Bolós, C. Down-regulation of FUT3 and FUT5 by shRNA alters Lewis antigens expression and reduces the adhesion capacities of gastric cancer cells. Biochim. Biophys. Acta Gen. Subj. 2011, 1810, 1141-1149. [CrossRef]

120. Ogawa, J.; Inoue, H.; Koide, S. a-2,3-Sialyltransferase Type 3N and a-1,3-Fucosyltransferase Type VII Are Related to Sialyl Lewisx Synthesis and Patient Survival from Lung Carcinoma. Cancer 1997, 79, 1678-1685. [CrossRef]

121. Barthel, S.R.; Wiese, G.K.; Cho, J.; Opperman, M.J.; Hays, D.L.; Siddiqui, J.; Pienta, K.J.; Furie, B.; Dimitroff, C.J. Alpha 1,3 fucosyltransferases are master regulators of prostate cancer cell trafficking. Proc. Natl. Acad. Sci. USA 2009, 106, 19491-19496. [CrossRef]

122. Inaba, Y.; Ohyama, C.; Kato, T.; Satoh, M.; Saito, H.; Hagisawa, S.; Takahashi, T.; Endoh, M.; Fukuda, M.N.; Arai, Y.; et al. Gene transfer of $\alpha 1,3$-fucosyltransferase increases tumor growth of the PC-3 human prostate cancer cell line through enhanced adhesion to prostatic stromal cells. Int. J. Cancer 2003, 107, 949-957. [CrossRef]

123. Yin, X.; Rana, K.; Ponmudi, V.; King, M.R. Knockdown of fucosyltransferase III disrupts the adhesion of circulating cancer cells to E-selectin without affecting hematopoietic cell adhesion. Carbohydr. Res. 2010, 345, 2334-2342. [CrossRef]

124. Ohyama, C.; Tsuboi, S.; Fukuda, M. Dual roles of sialyl Lewis X oligosaccharides in tumor metastasis and rejection by natural killer cells. EMBO J. 1999, 18, 1516-1525. [CrossRef]

125. Desiderio, V.; Papagerakis, P.; Tirino, V.; Zheng, L.; Matossian, M.; Prince, M.E.; Paino, F.; Mele, L.; Papaccio, F.; Montella, R.; et al. Increased fucosylation has a pivotal role in invasive and metastatic properties of head and neck cancer stem cells. Oncotarget 2010, 1, 71-84. [CrossRef]

126. Zhuang, H.; Hu, Z.; Tan, M.; Zhu, L.; Liu, J.; Liu, D.; Yan, L.; Lin, B. Overexpression of Lewis y antigen promotes human epididymis protein 4-mediated invasion and metastasis of ovarian cancer cells. Biochimie 2014, 105, 91-98. [CrossRef]

127. Hirakawa, M.; Takimoto, R.; Tamura, F.; Yoshida, M.; Ono, M.; Murase, K.; Sato, Y.; Osuga, T.; Sato, T.; Iyama, S.; et al. Fucosylated TGF- $\beta$ receptors transduces a signal for epithelial-mesenchymal transition in colorectal cancer cells. Br. J. Cancer 2014, 110, 156-163. [CrossRef]

128. Terao, N.; Takamatsu, S.; Minehira, T.; Sobajima, T.; Nakayama, K.; Kamada, Y.; Miyoshi, E. Fucosylation is a common glycosylation type in pancreatic cancer stem cell-like phenotypes. World J. Gastroenterol. 2015, 21, 3876-3887. [CrossRef]

129. Shan, X.; Aziz, F.; Tian, L.L.; Wang, X.Q.; Yan, Q.; Liu, J.W. Ginsenoside Rg3-induced EGFR/MAPK pathway deactivation inhibits melanoma cell proliferation by decreasing FUT4/LeY expression. Int. J. Oncol. 2015, 46, 1667-1676. [CrossRef]

130. Zhao, L.; Feng, X.; Song, X.; Zhou, H.; Zhao, Y.; Cheng, L.; Jia, L. MiR-493-5p attenuates the invasiveness and tumorigenicity in human breast cancer by targeting FUT4. Oncol. Rep. 2016, 36, 1007-1015. [CrossRef]

131. Cheng, L.; Luo, S.; Jin, C.; Ma, H.; Zhou, H.; Jia, L. FUT family mediates the multidrug resistance of human hepatocellular carcinoma via the PI3K/Akt signaling pathway. Cell Death Dis. 2013, 4, e923. [CrossRef]

132. Zheng, Q.; Cui, X.; Zhang, D.; Yang, Y.; Yan, X.; Liu, M.; Niang, B.; Aziz, F.; Liu, S.; Yan, Q.; et al. miR-200b inhibits proliferation and metastasis of breast cancer by targeting fucosyltransferase IV and $\alpha 1,3$-fucosylated glycans. Oncogenesis 2017, 6, e358. [CrossRef] 
133. Li, J.; Guillebon, A.D.; Hsu, J.-W.; Barthel, S.R.; Dimitroff, C.J.; Lee, Y.-F.; King, M.R. Human fucosyltransferase 6 enables prostate cancer metastasis to bone. Br. J. Cancer 2013, 109, 3014-3022. [CrossRef]

134. Liu, F.; Zhang, Y.; Zhang, X.-Y.; Chen, H.-L. Transfection of the nm23-H1 gene into human hepatocarcinoma cell line inhibits the expression of sialyl Lewis X, alpha1,3 fucosyltransferase VII, and metastatic potential. J. Cancer Res. Clin. Oncol. 2002, 128, 189-196. [CrossRef]

135. Liu, F.; Qi, H.L.; Zhang, Y.; Zhang, X.Y.; Chen, H.L. Transfection of the c-erbB2/neu gene upregulates the expression of sialyl Lewis $X$, alpha1,3-fucosyltransferase VII, and metastatic potential in a human hepatocarcinoma cell line. Eur. J. Biochem. 2001, 268, 3501-3512. [CrossRef]

136. Wang, H.; Wang, Q.-Y.; Zhang, Y.; Shen, Z.-H.; Chen, H.-L. Alpha1,3 Fucosyltransferase-VII modifies the susceptibility of apoptosis induced by ultraviolet and retinoic acid in human hepatocarcinoma cells. Glycoconj. J. 2007, 24, 207-220. [CrossRef]

137. Liang, J.; Gao, W.; Cai, L. Fucosyltransferase VII promotes proliferation via the EGFR/AKT/mTOR pathway in A549 cells. Onco Targets Ther. 2017, 10, 3971-3978. [CrossRef]

138. Wang, Q.Y.; Guo, P.; Duan, L.L.; Shen, Z.H.; Chen, H.L. $\alpha-1,3$-fucosyltransferase-VII stimulates the growth of hepatocarcinoma cells via the cyclin-dependent kinase inhibitor p27Kip1. Cell. Mol. Life Sci. 2005, 62, 171-178. [CrossRef]

139. Wi, G.R.; Moon, B.-I.; Kim, H.J.; Lim, W.; Lee, A.; Lee, J.W.; Kim, H.-J. A lectin-based approach to detecting carcinogenesis in breast tissue. Oncol. Lett. 2016, 11, 3889-3895. [CrossRef]

140. Ji, J.; Gu, X.; Fang, M.; Zhao, Y.; Yi, C.; Wang, A.; Gao, C. Expression of alpha 1,6-fucosyltransferase 8 in hepatitis B virus-related hepatocellular carcinoma influences tumour progression. Dig. Liver Dis. 2013, 45, 414-421. [CrossRef]

141. Kim, H.J.; Kim, S.C.; Ju, W.; Kim, Y.H.; Yin, S.Y.; Kim, H.J. Aberrant sialylation and fucosylation of intracellular proteins in cervical tissue are critical markers of cervical carcinogenesis. Oncol. Rep. 2014, 31, 1417-1422. [CrossRef]

142. Osumi, D.; Takahashi, M.; Miyoshi, E.; Yokoe, S.; Lee, S.H.; Noda, K.; Nakamori, S.; Gu, J.; Ikeda, Y.; Kuroki, Y.; et al. Core fucosylation of E-cadherin enhances cell-cell adhesion in human colon carcinoma WiDr cells. Cancer Sci. 2009, 100, 888-895. [CrossRef]

143. Osuga, T.; Takimoto, R.; Ono, M.; Hirakawa, M.; Yoshida, M.; Okagawa, Y.; Uemura, N.; Arihara, Y.; Sato, Y.; Tamura, F.; et al. Relationship between increased fucosylation and metastatic potential in colorectal cancer. J. Natl. Cancer Inst. 2016, 108, diw038. [CrossRef]

144. Liu, L.; Yan, B.; Huang, J.; Gu, Q.; Wang, L.; Fang, M.; Jiao, J.; Yue, X. The Identification and Characterization of Novel N-glycan-based Biomarkers in Gastric Cancer. PLoS ONE 2013, 8, e77821. [CrossRef]

145. Kim, Y.S.; Hwang, S.Y.; Oh, S.; Sohn, H.; Kang, H.Y.; Lee, J.H.; Cho, E.W.; Kim, J.Y.; Yoo, J.S.; Kim, N.S.; et al. Identification of target proteins of $\mathrm{N}$-acetylglucosaminyltransferase $\mathrm{V}$ and fucosyltransferase 8 in human gastric tissues by glycomic approach. Proteomics 2004, 4, 3353-3358. [CrossRef]

146. Zhao, Y.-P.; Xu, X.-Y.; Fang, M.; Wang, H.; You, Q.; Yi, C.-H.; Ji, J.; Gu, X.; Zhou, P.-T.; Cheng, C.; et al. Decreased core-fucosylation contributes to malignancy in gastric cancer. PLoS ONE 2014, 9, e94536. [CrossRef]

147. Tuccillo, F.M.; De Laurentiis, A.; Palmieri, C.; Fiume, G.; Bonelli, P.; Borrelli, A.; Tassone, P.; Scala, I.; Buonaguro, F.M.; Quinto, I.; et al. Aberrant glycosylation as biomarker for cancer: Focus on CD43. Biomed Res. Int. 2014, 2014. [CrossRef]

148. Ito, Y.; Miyauchi, A.; Yoshida, H.; Uruno, T.; Nakano, K.; Takamura, Y.; Miya, A.; Kobayashi, K.; Yokozawa, T.; Matsuzuka, F.; et al. Expression of $\alpha 1,6$-fucosyltransferase (FUT8) in papillary carcinoma of the thyroid: Its linkage to biological aggressiveness and anaplastic transformation. Cancer Lett. 2003, 200, 167-172. [CrossRef]

149. Kaptan, E.; Sancar-Bas, S.; Sancakli, A.; Bektas, S.; Bolkent, S. The effect of plant lectins on the survival and malignant behaviors of thyroid cancer cells. J. Cell. Biochem. 2018, 119, 6274-6287. [CrossRef]

150. Honma, R.; Kinoshita, I.; Miyoshi, E.; Tomaru, U.; Matsuno, Y.; Shimizu, Y.; Takeuchi, S.; Kobayashi, Y.; Kaga, K.; Taniguchi, N.; et al. Expression of fucosyltransferase 8 is associated with an unfavorable clinical outcome in non-small cell lung cancers. Oncology 2015, 88, 298-308. [CrossRef]

151. Chen, C.-Y.; Jan, Y.H.; Juan, Y.H.; Yang, C.J.; Huang, M.S.; Yu, C.J.; Yang, P.C.; Hsiao, M.; Hsu, T.L.; Wong, C.H. Fucosyltransferase 8 as a functional regulator of non-small cell lung cancer. Proc. Natl. Acad. Sci. USA 2013, 110, 630-635. [CrossRef] 
152. Jia, L.; Zhang, J.; Ma, T.; Guo, Y.; Yu, Y.; Cui, J. The Function of Fucosylation in Progression of Lung Cancer. Front. Oncol. 2018, 8,1-10. [CrossRef]

153. Wang, X.; Chen, J.; Li, Q.K.; Peskoe, S.B.; Zhang, B.; Choi, C.; A Platz, E.; Zhang, H. Overexpression of $\alpha(1,6)$ fucosyltransferase associated with aggressive prostate cancer. Glycobiology 2014, 24, 935-944. [CrossRef]

154. Yang, H.-F.; Yu, M.; Jin, H.-D.; Yao, J.-Q.; Lu, Z.-L.; Yabasin, I.B.; Yan, Q.; Wen, Q.-P. Fentanyl promotes breast cancer cell stemness and epithelial-mesenchymal transition by upregulating $\alpha 1,6$-fucosylation via Wnt/ $\beta$-catenin signaling pathway. Front. Physiol. 2017, 8, 1-12. [CrossRef]

155. Mehta, A.; Comunale, M.A.; Rawat, S.; Casciano, J.C.; Lamontagne, J.; Herrera, H.; Ramanathan, A.; Betesh, L.; Wang, M.; Norton, P.; et al. Intrinsic hepatocyte dedifferentiation is accompanied by upregulation of mesenchymal markers, protein sialylation and core alpha 1,6 linked fucosylation. Sci. Rep. 2016, 6, 27965. [CrossRef]

156. Abbott, K.L.; Nairn, A.V.; Hall, E.M.; Horton, M.B.; McDonald, J.F.; Moremen, K.W.; Dinulescu, D.M.; Pierce, M. Focused glycomic analysis of the N-linked glycan biosynthetic pathway in ovarian cancer. Proteomics 2008, 8, 3210-3220. [CrossRef]

157. Höti, N.; Yang, S.; Hu, Y.; Shah, P.; Haffner, M.C.; Zhang, H. Overexpression of $\alpha(1,6)$ fucosyltransferase in the development of castration-resistant prostate cancer cells. Prostate Cancer Prostatic Dis. 2018, 21, 137-146. [CrossRef]

158. Ferreira, I.G.; Pucci, M.; Venturi, G.; Malagolini, N.; Chiricolo, M.; Dall'Olio, F. Glycosylation as a main regulator of growth and death factor receptors signaling. Int. J. Mol. Sci. 2018, 19, 580. [CrossRef]

159. Zhou, Y.; Fukuda, T.; Hang, Q.; Hou, S.; Isaji, T.; Kameyama, A.; Gu, J. Inhibition of fucosylation by 2-fluorofucose suppresses human liver cancer HepG2 cell proliferation and migration as well as tumor formation. Sci. Rep. 2017, 7, 11563. [CrossRef]

160. Hu, P.; Shi, B.; Geng, F.; Zhang, C.; Wu, W.; Wu, X.Z. E-cadherin core fucosylation regulates nuclear beta-catenin accumulation in lung cancer cells. Glycoconj. J. 2008, 25, 843-850. [CrossRef]

161. Qin, R.; Zhao, J.; Qin, W.; Zhang, Z.; Zhao, R.; Han, J.; Yang, Y.; Li, L.; Wang, X.; Ren, S.; et al. Discovery of Non-invasive Glycan Biomarkers for Detection and Surveillance of Gastric Cancer. J. Cancer 2017, 8 , 1908-1916. [CrossRef]

162. Miyoshi, E.; Uozumi, N.; Noda, K.; Hayashi, N.; Hori, M.; Taniguchi, N. Expression of a1-6 Fucosyltransferase in Rat Tissues and Human Cancer Cells. Int. J. Cancer 1997, 72, 1117-1121. [CrossRef]

163. Shao, K.; Chen, Z.Y.; Gautam, S.; Deng, N.H.; Zhou, Y.; Wu, X.Z. Posttranslational modification of E-cadherin by core fucosylation regulates Src activation and induces epithelial-mesenchymal transition-like process in lung cancer cells. Glycobiology 2015, 26, 142-154. [CrossRef]

164. Miyoshi, E.; Noda, K.; Ko, J.H.; Ekuni, A.; Kitada, T.; Uozumi, N.; Ikeda, Y.; Matsuura, N.; Sasaki, Y.; Hayashi, N.; et al. Overexpression of $\alpha 1-6$ fucosyltransferase in hepatoma cells suppresses intrahepatic metastasis after splenic injection in athymic mice. Cancer Res. 1999, 59, 2237-2243.

165. Okagawa, Y.; Takada, K.; Arihara, Y.; Kikuchi, S.; Osuga, T.; Nakamura, H.; Kamihara, Y.; Hayasaka, N.; Usami, M.; Murase, K.; et al. Activated p53 with histone deacetylase inhibitor enhances L-Fucose-mediated drug delivery through induction of fucosyltransferase 8 expression in hepatocellular carcinoma cells. PLoS ONE 2016, 11, e0168355. [CrossRef]

166. Bernardi, C.; Soffientini, U.; Piacente, F.; Tonetti, M.G. Effects of MicroRNAs on Fucosyltransferase 8 (FUT8) Expression in Hepatocarcinoma Cells. PLoS ONE 2013, 8, e76540. [CrossRef]

167. Moloney, D.J.; Haltiwanger, R.S. The O-linked fucose glycosylation pathway. Identification and characterization of a uridine diphosphoglucose: Fucose- $\beta 1,3$-glucosyltransferase activity from Chinese hamster ovary cells. Glycobiology 1999, 9, 679-687. [CrossRef]

168. Vasudevan, D.; Haltiwanger, R.S. Novel roles for O-linked glycans in protein folding. Glycoconj. J. 2014, 31, 417-426. [CrossRef]

169. Stanley, P.; Okajima, T. Roles of glycosylation in notch signaling. In Current Topics in Developmental Biology; Academic Press: San Diego, CA, USA, 2010.

170. Aster, J.C.; Pear, W.S.; Blacklow, S.C. The Varied Roles of Notch in Cancer. Annu. Rev. Pathol. Mech. Dis. 2017, 12, 245-275. [CrossRef]

171. Taylor, P.; Takeuchi, H.; Sheppard, D.; Chillakuri, C.; Lea, S.M.; Haltiwanger, R.S.; Handford, P.A. Fringe-mediated extension of O-linked fucose in the ligand-binding region of Notch1 increases binding to mammalian Notch ligands. Proc. Natl. Acad. Sci. USA 2014, 111, 7290-7295. [CrossRef] 
172. Harvey, B.M.; Haltiwanger, R.S. Regulation of Notch Fuction by O-Glycosylation. In Molecular Mechanisms of Notch Signaling; Borggrefe, T., Giaimo, B.D., Eds.; Springer International Publishing: Cham, Switzerland, 2018.

173. Takeuchi, H.; Schneider, M.; Williamson, D.B.; Ito, A.; Takeuchi, M.; Handford, P.; Haltiwanger, R.S. Two novel protein $\mathrm{O}$-glucosyltransferases that modify sites distinct from POGLUT1 and affect Notch trafficking and signaling. Proc. Natl. Acad. Sci. USA 2018, 115, E8395-E8402. [CrossRef]

174. Ma, L.; Dong, P.; Liu, L.; Gao, Q.; Duan, M.; Zhang, S.; Chen, S.; Xue, R.; Wang, X. Overexpression of protein O-fucosyltransferase 1 accelerates hepatocellular carcinoma progression via the Notch signaling pathway. Biochem. Biophys. Res. Commun. 2016, 473, 503-510. [CrossRef]

175. Milde-Langosch, K.; Karn, T.; Schmidt, M.; zu Eulenburg, C.; Oliveira-Ferrer, L.; Wirtz, R.M.; Schumacher, U.; Witzel, I.; Schütze, D.; Müller, V. Prognostic relevance of glycosylation-associated genes in breast cancer. Breast Cancer Res. Treat. 2014, 145, 295-305. [CrossRef]

176. Kaufman, R.L.; Ginsburg, V. The Metabolism of L-Fucose by HeLa Cells. Exp. Cell Res. 1968, 50, $127-132$. [CrossRef]

177. Mullen, J.; Rosato, F.E.; Allen, T.R.; Miller, E.E.; Roseman, J.; Rosato, E.F. Continuous Intravenous Fucose Therapy in Rat Mammary Cancer II. J. Surg. Oncol. 1973, 5, 61-69. [CrossRef]

178. Tomsik, P.; Soukup, T.; Cermakova, E.; Micuda, S.; Niang, M.; Sucha, L.; Rezacova, M. L-rhamnose and L-fucose suppress cancer growth in mice. Cent. Eur. J. Biol. 2011, 6, 1-9. [CrossRef]

179. Stanková, J. Fucose-activated killer cells. I. Enhanced TNF-alpha mRNA accumulation and protein production. J. Leukoc. Biol. 1992, 52, 188-196. [CrossRef]

180. Zhang, Z.; Teruya, K.; Eto, H.; Shirahata, S. Induction of Apoptosis by Low-Molecular-Weight Fucoidan through Calcium- and Caspase-Dependent Mitochondrial Pathways in MDA-MB-231 Breast Cancer Cells. Biosci. Biotechnol. Biochem. 2013, 77, 235-242. [CrossRef]

181. Chen, S.; Zhao, Y.; Zhang, Y.; Zhang, D. Fucoidan induces cancer cell apoptosis by modulating the endoplasmic reticulum stress cascades. PLoS ONE 2014, 9, e108157. [CrossRef]

182. Zhang, Z.; Teruya, K.; Yoshida, T.; Eto, H.; Shirahata, S. Fucoidan extract enhances the anti-cancer activity of chemotherapeutic agents in MDA-MB-231 and MCF-7 breast cancer cells. Mar. Drugs 2013, 11, 81-98. [CrossRef]

183. Usoltseva, R.V.; Anastyuk, S.D.; Shevchenko, N.M.; Surits, V.V.; Silchenko, A.S.; Isakov, V.V.; Zvyagintseva, T.N.; Thinh, P.D.; Ermakova, S.P. Polysaccharides from brown algae Sargassum duplicatum: The structure and anticancer activity in vitro. Carbohydr. Polym. 2017, 175, 547-556. [CrossRef]

184. Usoltseva, R.V.; Anastyuk, S.D.; Ishina, I.A.; Isakov, V.V.; Zvyagintseva, T.N.; Thinh, P.D.; Zadorozhny, P.A.; Dmitrenok, P.S.; Ermakova, S.P. Structural characteristics and anticancer activity in vitro of fucoidan from brown alga Padina boryana. Carbohydr. Polym. 2018, 184, 260-268. [CrossRef]

185. Chen, H.; Cong, Q.; Du, Z.; Liao, W.; Zhang, L.; Yao, Y.; Ding, K. Sulfated fucoidan FP08S2 inhibits lung cancer cell growth in vivo by disrupting angiogenesis via targeting VEGFR2/VEGF and blocking VEGFR2/Erk/VEGF signaling. Cancer Lett. 2016, 382, 44-52. [CrossRef]

186. Lin, J.; Wang, K.; Wang, H.; Shao, Q.; Luan, Y.; Xu, Y.; Song, X.; Tan, W.; Liu, S.; Wei, F.; et al. Fucoidan reduced the invasion of oral squamous cell carcinoma cells and modified their effects to macrophages. Med. Oncol. 2017, 34, 9. [CrossRef]

187. Hsu, H.-Y.; Lin, T.-Y.; Lu, M.-K.; Leng, P.-J.; Tsao, S.-M.; Wu, Y.-C. Fucoidan induces Toll-like receptor 4-regulated reactive oxygen species and promotes endoplasmic reticulum stress-mediated apoptosis in lung cancer. Sci. Rep. 2017, 7, 44990. [CrossRef]

188. Wang, Z.-J.; Xu, W.; Liang, J.-W.; Wang, C.-S.; Kang, Y. Effect of Fucodian on B16 Murine Melanoma Cell Melanin Formation and Apoptosis. Afr. J. Tradit. Complement. Altern. Med. 2017, 14, 149-155. [CrossRef]

189. Rui, X.; Pan, H.F.; Shao, S.L.; Xu, X.M. Anti-tumor and anti-angiogenic effects of Fucoidan on prostate cancer: Possible JAK-STAT3 pathway. BMC Complement. Altern. Med. 2017, 17, 378. [CrossRef]

190. Ishikawa, C.; Mori, N. In vitro and in vivo anti-primary effusion lymphoma activities of fucoidan extracted from Cladosiphon okamuranus Tokida. Oncol. Rep. 2017, 38, 3197-3204. [CrossRef]

191. Thakur, V.; Lu, J.; Roscilli, G.; Aurisicchio, L.; Cappelletti, M. The natural compound fucoidan from New Zealand Undaria pinnatifida synergizes with the ERBB inhibitor lapatinib enhancing melanoma growth inhibition Fucoidan extracted from New Zealand. Oncotarget 2017, 8, 17887-17896. [CrossRef]

192. Shen, H.Y.; Li, L.Z.; Xue, K.C.; Hu, D.D.; Gao, Y.J. Antitumor activity of fucoidan in anaplastic thyroid cancer via apoptosis and anti-angiogenesis. Mol. Med. Rep. 2017, 15, 2620-2624. [CrossRef] 
193. Burney, M.; Mathew, L.; Gaikwad, A.; Nugent, E.K.; Gonzalez, A.O.; Smith, J.A. Evaluation Fucoidan Extracts from Undaria pinnatifida and Fucus vesiculosus in Combination with Anticancer Drugs in Human Cancer Orthotopic Mouse Models. Integr. Cancer Ther. 2018, 17, 755-761. [CrossRef]

194. Rillahan, C.D.; Antonopoulos, A.; Lefort, C.T.; Sonon, R.; Azadi, P.; Ley, K.; Dell, A.; Haslam, S.M.; Paulson, J.C. Global metabolic inhibitors of sialyl- and fucosyltransferases remodel the glycome. Nat. Chem. Biol. 2012, 8, 661-668. [CrossRef]

195. McKenzie, N.C.; Scott, N.E.; John, A.; White, J.M.; Goddard-Borger, E.D. Synthesis and use of 6,6,6trifluoro-L-fucose to block core-fucosylation in hybridoma cell lines. Carbohydr. Res. 2018, 465, 4-9. [CrossRef]

196. Kizuka, Y.; Nakano, M.; Yamaguchi, Y.; Nakajima, K.; Oka, R.; Sato, K.; Ren, C.-T.; Hsu, T.-L.; Wong, C.-H.; Taniguchi, N. An Alkynyl-Fucose Halts Hepatoma Cell Migration and Invasion by Inhibiting GDP-Fucose-Synthesizing Enzyme FX, TSTA3. Cell Chem. Biol. 2017, 24, 1467-1478. [CrossRef]

197. Fujii, H.; Shinzaki, S.; Iijima, H.; Wakamatsu, K.; Iwamoto, C.; Sobajima, T.; Kuwahara, R.; Hiyama, S.; Hayashi, Y.; Takamatsu, S.; et al. Core Fucosylation on T Cells, Required for Activation of T-Cell Receptor Signaling and Induction of Colitis in Mice, Is Increased in Patients with Inflammatory Bowel Disease. Gastroenterology 2016, 150, 1620-1632. [CrossRef]

198. Ghahremanloo, A.; Soltani, A.; Modaresi, S.M.S.; Hashemy, S.I. Recent advances in the clinical development of immune checkpoint blockade therapy. Cell. Oncol. 2019, 1-18. [CrossRef]

199. Kruger, S.; Ilmer, M.; Kobold, S.; Cadilha, B.L.; Endres, S.; Ormanns, S.; Schuebbe, G.; Renz, B.W.; D’Haese, J.G.; Schloesser, H.; et al. Advances in cancer immunotherapy 2019-latest trends. J. Exp. Clin. Cancer Res. 2019, 38, 1-11. [CrossRef]

200. Carrasco Hope, H.; Salmond, R.J. Targeting the tumor microenvironment and T cell metabolism for effective cancer immunotherapy. Eur. J. Immunol. 2019, 49, 1147-1152.

201. Goletz, C.; Lischke, T.; Harnack, U.; Schiele, P.; Danielczyk, A.; Rühmann, J.; Goletz, S. Glyco-engineered anti-human programmed death-ligand 1 antibody mediates stronger CD8 $\mathrm{T}$ cell activation than its normal glycosylated and non-glycosylated counterparts. Front. Immunol. 2018, 9. [CrossRef]

202. Wu, X.; Gu, Z.; Chen, Y.; Chen, B.; Chen, W.; Weng, L.; Liu, X. Application of PD-1 Blockade in Cancer Immunotherapy. Comput. Struct. Biotechnol. J. 2019, 17, 661-674. [CrossRef]

203. Li, C.-W.; Lim, S.-O.; Xia, W.; Lee, H.-H.; Chan, L.-C.; Kuo, C.-W.; Khoo, K.-H.; Chang, S.-S.; Cha, J.-H.; Kim, T.; et al. Glycosylation and stabilization of programmed death ligand-1 suppresses T-cell activity. Nat. Commun. 2016, 7, 1-11. [CrossRef]

204. Okada, M.; Chikuma, S.; Kondo, T.; Hibino, S.; Machiyama, H.; Yokosuka, T.; Nakano, M.; Yoshimura, A. Blockage of Core Fucosylation Reduces Cell-Surface Expression of PD-1 and Promotes Anti-tumor Immune Responses of T Cells. Cell Rep. 2017, 20, 1017-1028. [CrossRef]

205. Hao, Y.Y.; Lin, B.; Zhao, Y.; Zhang, Y.H.; Li, F.F.; Diao, B.; Ou, Y.L.; Zhang, S.L. alpha1,2-fucosyltransferase gene transfection influences on biological behavior of ovarian carcinoma-derived RMG-I cells. J. Mol. Cell Biol. 2008, 41, 435-442.

206. Liang, L.; Gao, C.; Li, Y.; Sun, M.; Xu, J.; Li, H.; Jia, L.; Zhao, Y. miR-125a-3p/FUT5-FUT6 axis mediates colorectal cancer cell proliferation, migration, invasion and pathological angiogenesis via PI3K-Akt pathway. Cell Death Dis. 2017, 8, e2968. [CrossRef]

207. Zhan, L.; Chen, L.; Chen, Z. Knockdown of FUT3 disrupts the proliferation, migration, tumorigenesis and TGF- $\beta$ induced EMT in pancreatic cancer cells. Oncol. Lett. 2018, 16, 924-930. [CrossRef]

208. Wang, A.; Lu, C.; Ning, Z.; Gao, W.; Xie, Y.; Zhang, N.; Liang, J.; Abbasi, F.S.; Yan, Q.; Liu, J. Tumor-associated macrophages promote Ezrin phosphorylation-mediated epithelial-mesenchymal transition in lung adenocarcinoma through FUT4/LeY up-regulation. Oncotarget 2017, 8, 28247-28259. [CrossRef]

(C) 2019 by the authors. Licensee MDPI, Basel, Switzerland. This article is an open access article distributed under the terms and conditions of the Creative Commons Attribution (CC BY) license (http://creativecommons.org/licenses/by/4.0/). 